\title{
Product-Process Matrix
}

\begin{abstract}
In the today's highly competitive global business landscape, customers demand personalised products and responsive distribution systems, hence fuelling the concept of Distributed Manufacturing (DM) as a paradigm that suggests the geographical distribution of manufacturing systems adjacent to the markets to enable 'production on demand'. To this end, the objective of this research is to explore the DM concept to inform firms about the dynamically changing manufacturing environment, along with the emerging opportunities, and support business stakeholders in implementing DM-oriented strategies to achieve digitalisation, personalisation, and localisation. More specifically, the present research builds upon the Dynamic Capability Theory (DCT) and conducts semi-structured interviews with a panel of 16 experts from the Fast-Moving Consumer Goods, Automotive, and Engineering industries to develop 12 exploratory industry cases. Our analysis highlights that companies can adopt three strategies to implement DM and realise shorter lead times and personalised product offerings, namely: (i) small-scale DM; (ii) in-house decoupled manufacturing; and (iii) outsourced decoupled manufacturing. However, the economic viability of the DM concept is identified as a significant barrier to relinquish the traditional centralised economies-of-scale. This research contributes by applying the DCT to the DM concept to advocate the viability and sustainability of manufacturing systems in the era of Industry 4.0. Pertaining to the originality of this research, limited work is available on the applicability of DM in industries, from the DCT perspective, to accomplish competitive advantages in the dynamic environment of manufacturing.
\end{abstract}

Keywords: Distributed Manufacturing; Dynamic Capability Theory; Digitalisation; Personalisation; Localisation; Product-Process Matrix. 


\section{Introduction}

The concept of 'Industry 4.0', that in principal advances digitisation in manufacturing by supporting increased industrial flexibility and product customisation through automation and data sharing, is termed alternatively in different national settings (Sung, 2018). For example, a slightly refined version of 'Industry 4.0' is called 'Re-Distributed Manufacturing' in the United Kingdom (UK) whereas the term used in the United States of America is 'Smart Manufacturing'. The variant concepts might be used interchangeably, as they share the same scope for promoting manufacturing intelligence and responsiveness, but actually differ in terms of context: (i) 'Industry 4.0' predominantly focuses on the digital integration of factories and plants to enable automated engineering applications (Muhuri et al., 2019); (ii) 'Re-Distributed Manufacturing' leverages digital technology-enabled small-scale manufacturing to allow localised production and consumption models (Moreno et al., 2018); and (iii) 'Smart Manufacturing' uses factory-level data to derive manufacturing intelligence (O'Donovan et al., 2015). Regardless of the terminology adopted, the global prospects of the 'Industry 4.0' umbrella concept indicate the expected value implications for digital manufacturing networks. Indicatively, the 'Industry 4.0' market was valued at USD 66.67 billion in 2016 and is projected to reach USD 152.31 billion by 2022, at a compound annual growth rate of about 15\% (Markets and Markets, 2017).

Historically, manufacturing has evolved from craft production, during the $1^{\text {st }}$ Industrial Revolution, to mass production followed by mass customisation as the $2^{\text {nd }}$ and $3^{\text {rd }}$ Industrial Revolutions (Love \& Gunasekaran, 1997), respectively. However, the dynamically changing industrialised environment (Kumar \& Gregory, 2013), along with advancements in digital manufacturing technologies (Srai, Kumar et al., 2016), is at the pinnacle of yet another revolution that aims to provide improved customisation, digitalisation and regionalisation of products and services in the $21^{\text {st }}$ century (Koren, 2010). An indicative example is the German concept of 'Industrie 4.0' which is predicted to transform manufacturing via the Internet of Things (IOT) business 
ecosystem (Rymaszewska et al., 2017), intelligent autonomous robotic systems (Bechtsis et al., 2017), and additive manufacturing technological applications (Rejeski et al., 2018). This nexus of digital transformation drivers would have an impact on the adaptive capacity of manufacturing industries to tailor their business models accordingly and reflect customer demand patterns (Weller et al., 2015). An additional paradigm is the 'Circular Economy' concept which focuses on value optimisation by smart management of human and natural resources to explore the social and environmental implications of manufacturing in present and future scenarios (Rauch et al., 2016). However, there is an exigent need to explore a much broader concept that encompasses industrial indicators, customer demands, new technologies, and political issues, along with socioeconomic and environmental considerations, for a thorough analysis of future manufacturing scenarios (Kumar \& Gregory, 2013).

In the light of the abovementioned advancements and industrial challenges, Distributed Manufacturing (DM) follows an agile and user-driven approach that allows the manufacturing of personalised products at multiple scales and across different geographical locations (Moreno \& Charnley, 2016), considering that "technological developments in engineering and computing bring new capabilities to manufacturing in terms of automation, complexity, flexibility and efficiency" (Srai, Kumar et al., 2016). Despite the considerable research to understand DM along with the associated advantages and implementation barriers, there is, nonetheless, a lack of theory-based and casevalidated frameworks that could guide the implementation of DM in an industrial context.

Taking into account the myriad of nation-wide factors that impact the adoption of digital manufacturing paradigms (e.g. culture, education level, economic outlook, political instability etc.), a framework that could inform the implementation of 'Industry 4.0 ' is lacking, especially for the case of emerging economies that focus on the extraction and commercialisation of commodities (Dalenogare et al., 2018). At a greater extent, the investigation of the product-process interplay in technology-enabled manufacturing paradigms is eminent to advise tailored quality management practices and fulfil the expectations of global customers (Gunasekaran et al., 2019). In addition, a 
paucity of use cases that validate the DM concept exists in the extant literature; however, several illustrative real-world examples about the characteristics of DM manifest the advantages and disadvantages of the concept (Helo et al., 2014). In this sense, real-world exploratory industry cases are essential for understanding the product-process nexus in diverse manufacturing contexts to develop dynamic capabilities and further: (i) ensure supply chain resilience in today' uncertain environment (Chowdhury \& Quaddus, 2017); (ii) overcome distributed manufacturing adoption barriers (Kamble et al., 2018); and (iii) support the digital technology-enabled manufacturing roadmap towards the Sustainable Development Goals of the United Nations (Quezada et al., 2017).

In order to address the aforementioned gaps in the Operations Management field, a framework that conceptualises the underpinning interrelated routines in the dynamically evolving productprocess nexus is needed so as to develop capabilities for establishing DM supply network operations (Peng et al., 2008). In particular, considering the dominant characteristics of DM, namely 'digitalisation, personalisation, localisation, new manufacturing technologies, multi-user participation' (Srai, Kumar et al., 2016), developing dynamic capabilities would allow global manufacturing networks to 'sense' the landscape, 'seize' opportunities and 'reconfigure' resources to harness sustainable competitive advantages (Kumar et al., 2018). However, to the best of our knowledge, prior studies adopting the dynamic capabilities view either myopically study managerial and organizational capabilities in individual factories (Eriksson et al., 2014), or explore firms' competitiveness pursued via alternative marketing (Cao et al., 2018), innovation (Furlan \& Vinelli, 2018) and entrepreneurial orientations (Jiang et al., 2018). From a manufacturing network perspective, the dynamic capabilities analysis approach has been used to assess supply chain resilience (Chowdhurya \& Quaddus, 2017), hence denoting a clear void regarding the DM field.

This research presents a theoretically and empirically derived framework for the application of DM in response to dynamically changing technologies and customer demand structures to overcome the barriers of digital transformation and ensure a DM-driven competitive advantage to firms. The provided framework is underpinned by the Dynamic Capability Theory (DCT) (Teece et al., 1997) as 
appropriate to establish implementation strategies for DM (Yao \& Deng, 2016). The embracing of the DCT is deemed appropriate considering that manufacturing supply networks are recognised in the extant literature as complex adaptive systems that exhibit dynamism (Choi et al., 2001). We further attempt to gain a pragmatic view over the DM issue through conducting semi-structured interviews with a panel of 16 experts from the Fast-Moving Consumer Goods, Automotive, and Engineering industries to develop 12 exploratory industry cases. The analysis of diverse products and processes for DM applicability lays the foundations for addressing the following key research questions (RQs):

- RQ\#1 - What are the key characteristics of DM that enable its applicability in industrial supply networks?

- $\mathrm{RQ \# 2} \mathrm{-} \mathrm{How} \mathrm{multinational} \mathrm{corporations} \mathrm{can} \mathrm{adopt} \mathrm{DM} \mathrm{in} \mathrm{their} \mathrm{supply} \mathrm{network} \mathrm{operations}$ from the perspectives of product and process?

- RQ\#3 - Which are the implementation phases that enable the application of DM in industrial network systems to establish a sustainable competitive advantage?

All the above RQs are critical to be answered since DM is apprehended as the ideal manufacturing approach in the field of production science (Rauch \& Dallasega, 2017), especially in emerging markets, without the suitability of this model for economic viability and industrial sustainability been validated yet. More specifically, the answer to RQ\#1 will identify the key characteristics that drive and enable the applicability of DM in industrial supply networks. Following that, the answer to RQ\#2 will provide a critical analysis of exploratory cases as a roadmap that guides the application of DM in industries to establish a sustainable competitive advantage. Finally, in an attempt to answer RQ\#3, we propose a framework based on the DCT.

This study follows a multi-method approach to tackle all the enunciated research queries. More specifically, literature findings are utilised to answer RQ\#1. Both literature findings and expert 
interviews are employed for addressing RQ\#2. Finally, the formulation and analysis of industry cases provide an answer to RQ\#3 and reveal future research pathways.

The remainder of this paper is structured as follows. Section 2 describes the materials and methods related to this research by initially defining DM and its characteristics, through a literature review, while the theoretical underpinning of DCT to DM is further exemplified. The research methodology and design used to gather data and analyse the various aspects of DM are described, as well. Section 3 presents the results of the exploratory industry case studies. The discussion of multiple trends, advantages and disadvantages of DM, along with a cross-case analysis and the proposed DM implementation framework are presented in Section 4. Conclusions, limitations and recommendations for future research are discussed in the final Section 5.

\section{Materials and Methods}

In order to achieve a coherent conceptual structure of a topic with actual ramifications, the object of scrutiny should be a synthesis of the extant literature (Tranfield et al., 2003) along with the analysis of real-world case studies (Gibbert et al., 2008). The basic terminology, theoretical lens, methodological approach and materials relevant to this research are detailed in the following subsections.

\subsection{Basic terminology}

As the focus of this research is DM, it is necessary to define the term in this context. The DM concept implies the provision of personalised products along with other characteristics such as digitalisation, localisation and use of advanced manufacturing technologies (Srai, Kumar et al., 2016). Existing literature on DM addresses various trends, opportunities and challenges (Rauch et al., 2016), along with emerging industrial systems and manufacturing capabilities (Srai, Harrington et al., 2016). A standard definition of DM is: "... the shift from centralised to decentralised manufacturing with the aim to create a more resilient and connected system taking advantage of digital intelligence and 
newly emerging technologies, to provide agile, user-driven approach that will allow for personalisation and customisation of products to local markets" (Moreno \& Charnley, 2016).

There are numerous themes within the DM paradigm which are classified into three different concepts, based on the level of knowledge and resource proximity to the consumer (Moreno \& Charnley, 2016), namely: (i) distributed production and services; (ii) connected production and services; and (iii) localised production and services. DM is further classified in the literature based on collaborative schemes with different entities within a supply network, characterised by a high degree of modularity and non-hierarchic relationships (Mourtzis \& Doukas, 2012). Preliminary simulation models have also been developed that enable data-driven experimentation for DM and allow assessment of present and future manufacturing scenarios (Turner et al., 2017). Simulation models capture key imperatives of context, structure and strategy via an environment-formfunction-performance framework to understand the evolution of business ecosystems (Mintzberg et al., 2008). Barring the existing simulation models, limited theoretical underpinning available for DM in literature has been published (Srai, Kumar et al., 2016), thus far.

Srai, Kumar et al. (2016) have recognised five major characteristics of DM, namely: (i) digitalisation, (ii) personalisation; (iii) localisation; (iv) new manufacturing technologies; and (v) multi-user participation. The scope of this research focuses on the first four characteristics while multi-user participation is neglected as it refers to a DM characteristic that may not be favourable to manufacturing firms at this point of time. The DM characteristics are elaborated in the following sub-sections.

\subsubsection{Digitalisation}

A considerable amount of studies investigating the digitalisation aspect of manufacturing exists (Wang et al., 2016). Digitalisation of manufacturing implies the integration of information and knowledge between production and planning levels, further expanding to customers and suppliers (Moreno \& Charnley, 2016). Additionally, digitalisation enables a connected, localised and inclusive 
model of consumer goods production and consumption that is driven by the exponential growth and embedded value of big data (Turner et al., 2017). The main components of digitalisation are defined in Table 1:

Table 1. Digitalisation - Components and definitions.

\begin{tabular}{c|l}
\hline Component & \multicolumn{1}{c}{ Definition } \\
\hline $\begin{array}{c}\text { Internet of Things } \\
\text { (IOT) }\end{array}$ & $\begin{array}{l}\text { loT in manufacturing, from a technical perspective, envisions to connect every } \\
\text { element of a manufacturing system to the Internet and provide, from a } \\
\text { practical viewpoint, context-sensitive information to the right people at the } \\
\text { right time to propel the related decision-making process (Butala et al., 2013). }\end{array}$ \\
\hline $\begin{array}{c}\text { Cloud } \\
\text { Cloud Computing }\end{array}$ & $\begin{array}{l}\text { Cloud Manufacturing or Cloud Computing aims at integrating autonomous } \\
\text { agents, multiple clients and various suppliers on a single cloud platform to } \\
\text { optimise manufacturing operations (Mishra et al., 2016). }\end{array}$ \\
\hline Smart Factory & $\begin{array}{l}\text { Smart Factory comprises a set of smart machinery and conveyers that can } \\
\text { communicate with each other to reconfigure dynamically for enabling the } \\
\text { flexible production of multiple product types (Wang et al., 2016). }\end{array}$ \\
\hline
\end{tabular}

Regarding the implementation of digitalisation, key barriers discussed in the literature include

(Lee et al., 2013): (i) cyber security risks that could disclose sensitive information about critical manufacturing operations; (ii) lack of mature information and communications technology infrastructure for complete digitalisation of manufacturing; and (iii) deadlocks that result in decisionmaking collisions and overlapping.

\subsubsection{Personalisation}

According to Kohtala (2015), personalisation is realised through a high degree of product change, end-user experience and co-creation with the customer in order to adjust the product design and manufacturing process with the objective to develop a tangible artefact. In an industrial context, the provision of personalisation in a cost-effective manner is also termed as mass customisation where products are personalised in the later stages of the manufacturing process (Mourtzis \& Doukas, 2014). In this vein, the various levels of personalisation are well segregated in the literature (Spallek \& Krause, 2016), as inserted in Table 2.

Table 2. Personalisation - Components and definitions. 


\begin{tabular}{c|l}
\hline Component & \multicolumn{1}{c}{ Definition } \\
\hline Individualisation & $\begin{array}{l}\text { Individualisation strategies aim to satisfy each customer as an individual with } \\
\text { implicit needs so that the final product, as well as the basic design and } \\
\text { product structure, are changeable, adaptable, configurable and consequently } \\
\text { less predictable (Tseng et al., 2010). }\end{array}$ \\
\hline $\begin{array}{c}\text { Product Family } \\
\text { Design }\end{array}$ & $\begin{array}{l}\text { Product Family Design aims for sufficient external product variants combined } \\
\text { with manageable internal variety to obtain economies-of-scale at the } \\
\text { component level and to reduce complexity in the development and } \\
\text { manufacturing capabilities (Krause et al., 2014). }\end{array}$ \\
\hline Mass Customisation & $\begin{array}{l}\text { Mass Customisation aims to fulfil individual customer needs at a cost level } \\
\text { that satisfies a large share of the market (Blecker et al., 2006). }\end{array}$ \\
\hline
\end{tabular}

Certain limitations to personalised manufacturing include: (i) lack of more integrated, responsive and adaptive solutions to achieve personalised manufacturing (Mourtzis \& Doukas, 2013); (ii) lack of Life Cycle Assessment studies regarding the tooling, infrastructure or new technologies adopted to produce personalised products (Mai et al., 2016); and (iii) lack of governmental policies that regulate ownership of products' digital designs (Mourtzis et al., 2016a).

\subsubsection{Localisation}

The small-scale manufacturing dedicated to fulfilling local needs, in a flexible supply network of regional socio-economic actors using local resources, is called localisation (Kohtala, 2015). Reshoring, re-localisation and glocalisation are similar terms and concepts in literature to describe the concept of localisation. Manufacturing in a regional context could enhance localisation by enabling frugal innovations to provide cost-efficient and added-value local market solutions (Mourtzis et al., 2016b). Furthermore, the smart city concept has been propagated as an enabler of localisation, from a city perspective, such that supply and demand are fulfilled within urban boundaries (Kumar et al., 2016). Urban compatible manufacturing could integrate manufacturing operations in the city structure, hence limiting freight and public transportation needs with subsequent social benefits (Matt et al., 2018). Especially, Jaegler \& Burlat (2014) analysed the environmental impact of localisation, in terms of $\mathrm{CO}_{2}$ emissions, using plant location parameters to delineate product delivery networks (Table 3). 
Table 3. Localisation - Classification of supply networks based on Jaegler \& Burlat (2014).

\begin{tabular}{c|c|c|c|c}
\hline Plant Location & Local & Regional & Continental & Global \\
\hline \multirow{2}{*}{ Distance in km } & 50 & 500 & 1,800 & 8,000 \\
& & & & \\
\hline
\end{tabular}

In terms of barriers to localisation, four key impediments are documented in the literature, including: (i) competition with low-cost manufacturing locations in the world (Jaegler \& Burlat, 2014); (ii) quality and availability of locally sourced resources (Bailey \& De Propris, 2014); (iii) collaboration efficiency between manufacturers and suppliers for the management of resourcebased product and production network configurations (Belkadi et al., 2016); and (iv) availability of financial instruments to support relocation of manufacturing operations for localisation (Ashby, 2016).

\subsubsection{New manufacturing technologies}

Innovative manufacturing technologies like intelligent autonomous robotic systems, additive manufacturing and cyber-physical systems, are making a significant impact on manufacturing operations. The most pertinent definitions for such technologies, as found in the literature, are listed in Table 4.

Table 4. New manufacturing technologies - Components and definitions.

\begin{tabular}{c|l}
\hline Component & \multicolumn{1}{c}{ Definition } \\
\hline Robotics & $\begin{array}{l}\text { Robotics or robot technology could be described as intelligent artificial beings, } \\
\text { typically made of metal, capable of executing intellectually demanding human } \\
\text { tasks (Waytz \& Norton, 2014). }\end{array}$ \\
$\begin{array}{c}\text { Additive } \\
\text { Manufacturing }\end{array}$ & $\begin{array}{l}\text { Additive Manufacturing, widely refered to as 3D printing, suggests that a } \\
\text { technical design, generated using a three-dimensional Computer Aided } \\
\text { Design system, can be fabricated directly without the need for process } \\
\text { planning (Gibson et al., 2010). }\end{array}$ \\
\hline Cyber-Physical & $\begin{array}{l}\text { Cyber-Physical Systems are defined as the systems where the physical and } \\
\text { software components are intertwined, operate on different spatial and } \\
\text { temporal scales, exhibit multiple and distinct behavioural modalities, and } \\
\text { interact in a myriad of ways that alter with context (Khaitan \& McCalley, } \\
\text { 2015). }\end{array}$ \\
\hline
\end{tabular}




\begin{tabular}{c|l}
\hline Component & \multicolumn{1}{c}{ Definition } \\
\hline Mini-Factories & $\begin{array}{l}\text { Mini-Factories are flexible and rapidly reconfigurable small-scale factories for } \\
\text { the geographically distributed manufacturing of products ensuring both } \\
\text { product and quantity flexibility (Matt et al., 2015). }\end{array}$ \\
\hline
\end{tabular}

The main challenges that need to be addressed in future research, prior to the commercialisation of new manufacturing technologies, include: (i) limited workability to several plastics and metals with few applications (Wittbrodt et al., 2013); (ii) limited research on new technologies' manufacturing efficiency in terms of speed, quality and cost (Weller et al., 2015); and (iii) high energy consumption of numerous innovative manufacturing processes (Huang et al., 2013).

\subsection{Theoretical lens}

The DCT measures a firm's potential in adapting, integrating, and reconfiguring internal and external organisational skills, resources and functional competencies to match the requirements of a changing environment and hence gain a competitive advantage (Teece et al., 1997). In this sense, the DCT emerges from the characteristics of DM and could be used to provide a comprehensive substrate for understanding future impacts of specific technologies and trends. Therefore, this research adopts the DCT, outlined by Schumpeter (1934), as the theoretical lens.

The resource-based view of the DCT suggests developing firm-specific strategic capabilities or resources (Enrriquez-De-La-O, 2015); the resource-based view is used to describe a firm's resource utilisation strategy towards achieving competitive advantages, while the DCT focuses on the firm's strategy to sustain a competitive advantage (Teece et al., 1997). In manufacturing innovation, the DCT is generally applied to develop a framework that accommodates new technological or strategical developments while maintaining the organisation as a single and coherent entity (Wilson \& Daniel, 2007). This could enhance a firm's performance, thereby providing a competitive advantage even during the transition phase.

\subsection{Research approach}


The objective of this research is to provide a methodological framework for DM application to the way research findings can be accepted as knowledge in the literature (Saunders et al., 2015). In this sense, qualitative research is necessary, involving subject matter expert inputs, to construct and appreciate different perspectives and experiences of informants on the issue under study (Noor, 2008). Therefore, the Interpretivism research philosophy is selected to undertake in-depth, qualitative investigations of a small group of companies (Saunders et al., 2015). This approach is also tailored to the validation of identified DM characteristics identified as it interprets and analyses qualitative data rather than quantifying them through Positivism (Denzin \& Lincoln, 1994).

In the context of the Interpretivism research philosophy, qualitative research strategies could involve surveys, interviews, focus groups, observations, case studies, documents and records (Frechtling, 2002). Therefore, case study analysis would be ideal to empirically enquire about DM (contemporary phenomenon) within various industries (real-life context). Moreover, control of behavioural events is not required, thus experiments or observations can be ignored from the research strategy (Yin, 2009).

Exploratory case studies can have three research purposes: (i) exploratory (key variables not defined); (ii) descriptive (key variables defined); and (iii) explanatory (key variables and relationships defined). Also, as the context of this research is ignorant to industries, an exploratory study is required to construct the DM implementation theory (Edmondson \& McManus, 2007). Therefore, industrial case studies were developed based on interviews with 16 participants representing 12 multinational companies. The anonymised firms, for confidentiality reasons, along with a brief description of the product offerings and end-customers are presented in Table A1 at the Appendix. 
In particular, the involved companies are representative of three industries, to capture a wide range of products and manufacturing processes, namely: (i) fast-moving consumer goods (FMCG); (ii) automotive; and (iii) engineering. Companies were contacted using industry-specific templates which were followed by semi-structured interviews. A detailed explanation of DM, adapted from the Engineering and Physical Sciences Research Council (Pearson et al., 2013), was also provided during the interviews to impart the questionnaire's implications. Thereafter, we mapped each of the firms based on the product and process structure through leveraging the 'product-process matrix' concept introduced by Hayes \& Wheelwright (1979) who set the foundation of the strategic manufacturing theory. The 'product-process matrix' concept was later validated by Spencer \& Cox (1995) and is used today to strategically position a firm, particularly with regard to its manufacturing function.

Figure 1 outlines the mapping of the firms involved in this research, as these are denoted by the letters ' $A$ ' to ' $L$ '. The horizontal axis represents product life cycle phases while the vertical axis captures stages of a production process. The mapping results were generated by the informants by positioning each representative company/industry in the provided product-process correlation matrix, hence entailing a level of subjectivity. 


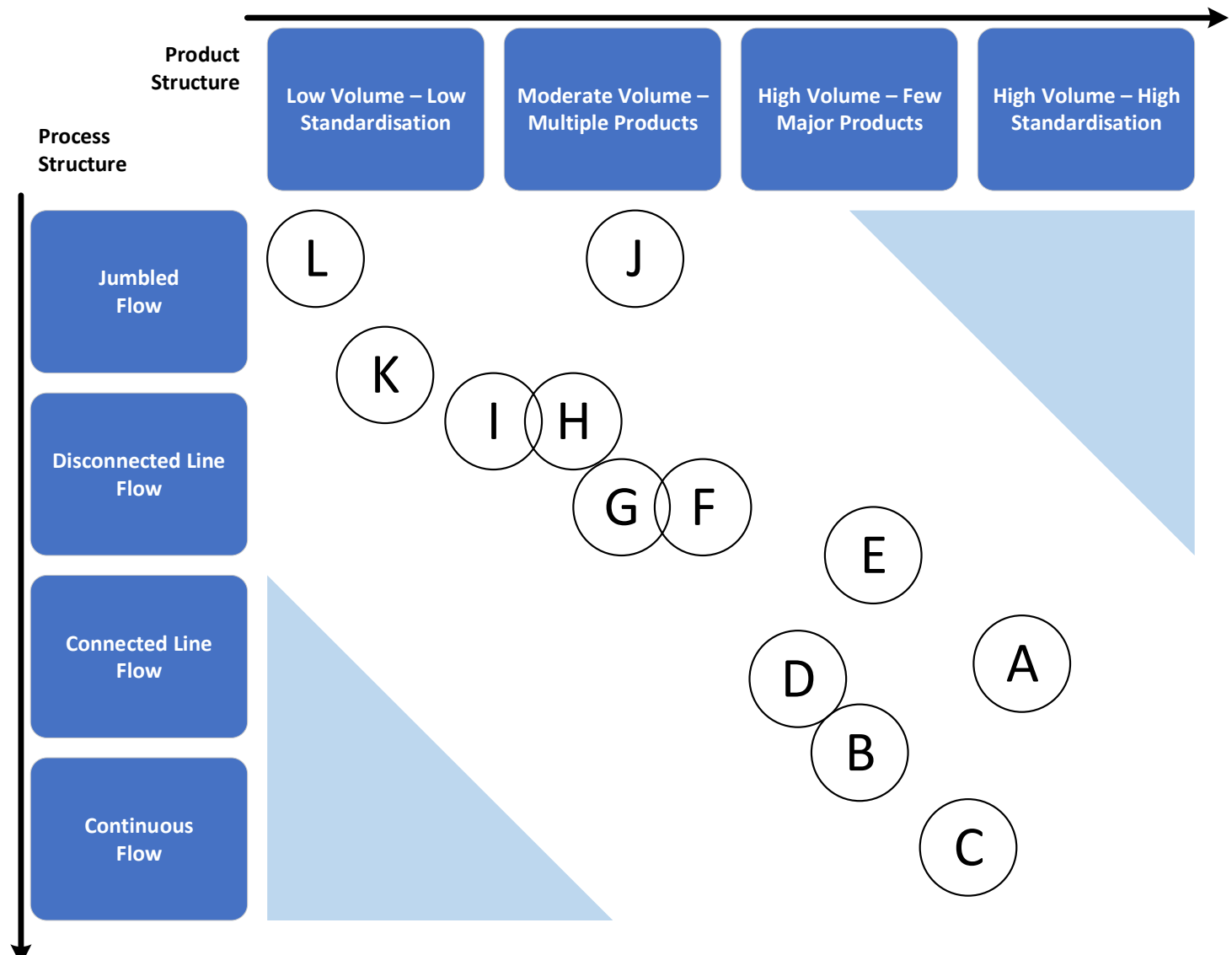

Figure 1. Industry case selection and mapping based on the 'product-process matrix' adopted by Hayes \& Wheelwright (1979).

\section{Results}

In this section, we adopt the 'case description development' strategy described by Yin (2009) to organise the retrieved data into matrices of various categories, i.e. the DM characteristics and supporting evidence was attributed on each category (Schwandt, 1994). The DM characteristic 'Multi-user Participation' (Srai, Kumar et al., 2016) was not included in the case study analysis due to its insignificance in the interview results. We map the DM characteristics of each involved firm to their respective components, advantages and disadvantages. The following sections provide the present and future manufacturing scenarios of the participant companies while these scenarios are mapped based on the characteristics of DM. 


\subsection{Case overview: Present and future scenarios}

Initially, the purpose of every interview was to explore the involved companies' operations, along with the corporate product and service offerings. To further comprehend the present manufacturing scenario at each participant company, the gathered responses are mapped based on the characteristics of DM. Table 5 illustrates the nature of operations and the current focus on DM characteristics, along with the ranking of the Key Performance Indicators (KPIs) that the companies under study elaborate. For evaluating the performance variables, we adopted the scaling system described by Safizadeh et al. (1996) and used ratings from ' 1 ' to ' 5 ' to denote a 'Very High' to a 'Very Low' priority for the assessed KPIs, respectively.

Following that, the impact of new technologies and upcoming trends in manufacturing is assessed. In particular, the retrieved data is used to generate a future expected scenario for each participant company and estimate the potential digital transformation barriers in the future (Table 6). The assessment of the expected impediments follows the same scale, using ratings from ' 1 ' to ' 5 ' to denote the 'Most Significant' to the 'Least Significant' barrier, respectively. 
Table 5. Case overview - Present scenario.

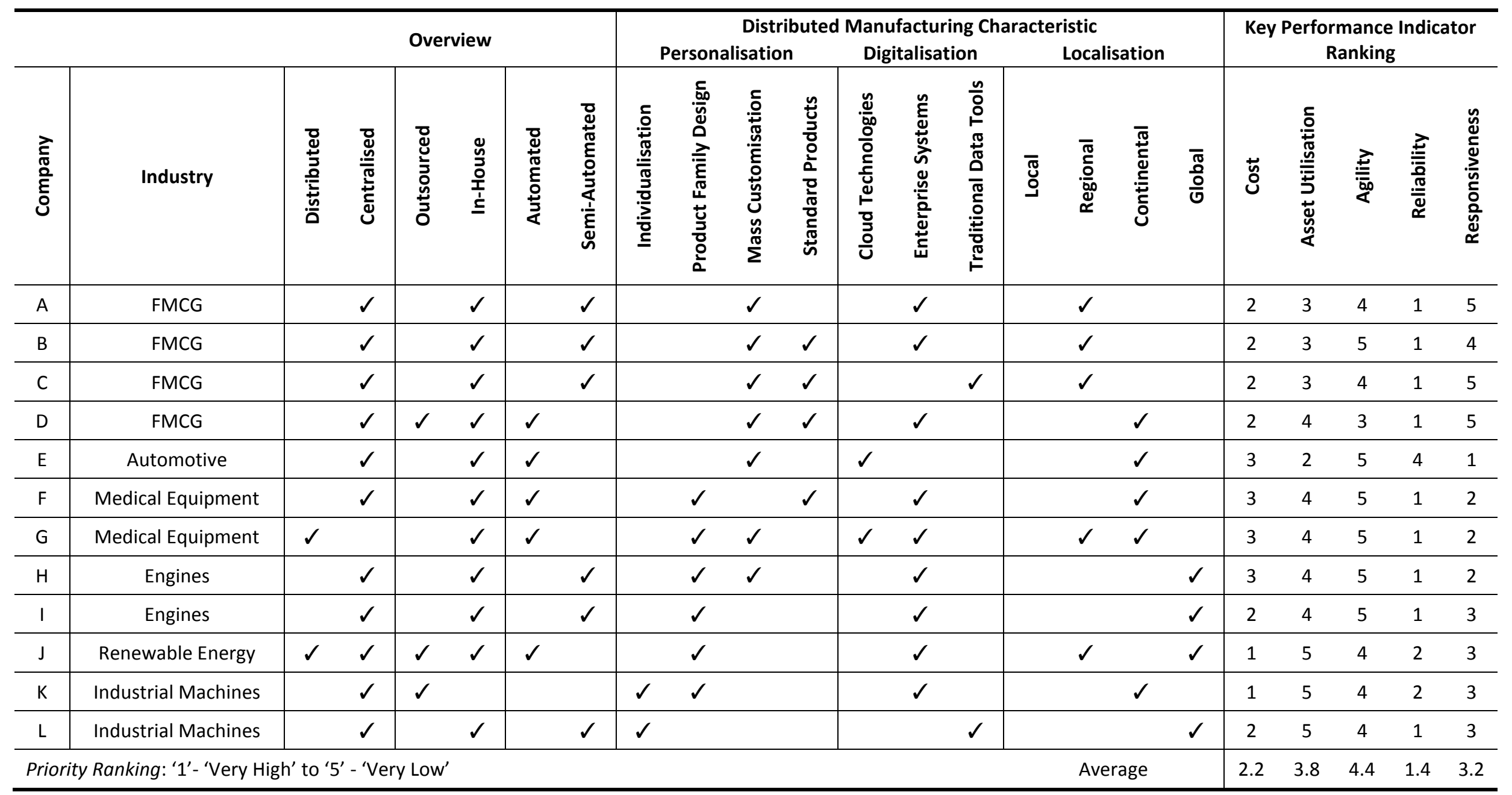


Table 6. Case overview - Future scenario.

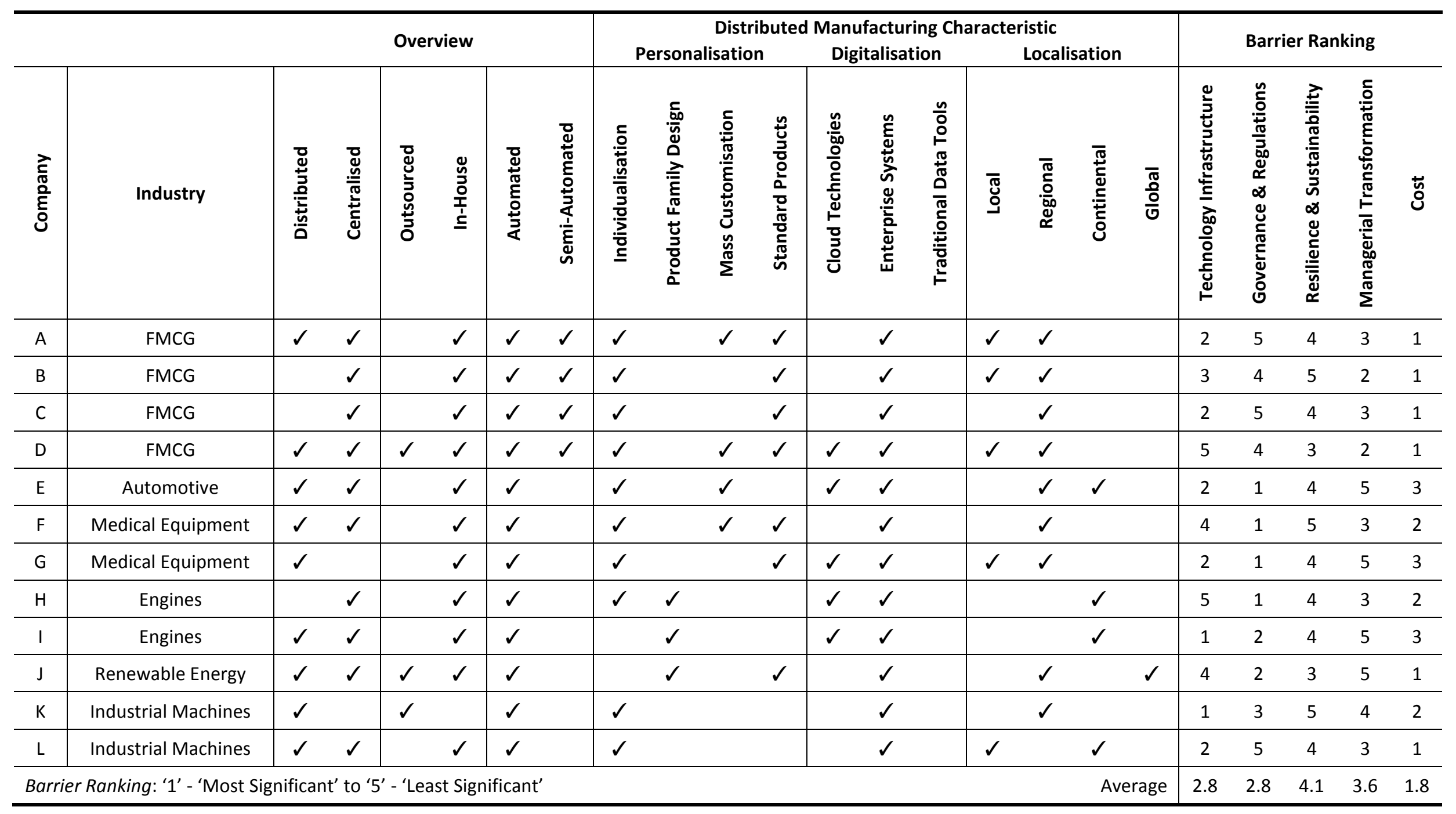



the case of high-end products (i.e. companies $E, F, G, H, I, J, K, L$ ) customers are provided with more personalisation. However, in the future scenario, all firms aim to provide personalisation as an additional feature to their standard/mass customised range of offerings.

Currently, most of the companies have Enterprise Resource Planning (ERP) systems installed for their operations. Companies $E$ and $G$ also use an aspect of cloud technologies for demand forecasting and supply chain optimisation (Table 5). However, it can be observed that companies offering products of moderate volume and price are inclined to adopt cloud technologies in the future (Table 6). Companies with high volume products do not require sophisticated digital tools for their standard products, whereas companies with low volume offerings can efficiently manage supply chains with existing digital infrastructure.

In terms of localisation, companies $G$ and $J$ apply different strategies for different products/components (Table 5); however, the localisation degree inversely correlates to product cost since logistics expenditure becomes insignificant compared to product cost. In the future scenario, more companies would seek to divide the manufacturing operations into different degrees of localisation (Table 6). Localisation is an unusual characteristic in terms of generalising since it depends on various properties of the product and manufacturing process.

Regarding KPIs, 'Reliability' is assigned the highest priority for most of the companies (i.e. companies $A, B, C, D, F, G, H, I, L)$. 'Cost' is ranked second and is regarded as a top-three priority for 
all companies. Following that, 'Responsiveness' and 'Asset Utilisation' are usually placed $3^{\text {rd }}$ and $4^{\text {th }}$ (Table 5).

Regarding the barriers to achieve DM, industries consider diverse challenges in the future. For example, 'Governance \& Regulations' is ranked the highest among particular industries like medical equipment and automotive (i.e. companies $E, F, G$ ). Furthermore, many companies (i.e. companies $A, B, C, D, J, L)$ are concerned about the economic viability of the DM model. 'Technology Infrastructure' is tied with 'Governance \& Regulations' since companies are not structured for the distributed model, thus recognising 'Cost' as the most prominent barrier. The 'Managerial Transformation' and 'Resilience \& Sustainability' have the least significance since companies are not hesitant in investing in new concepts for nurturing a competitive advantage in their specific industry (Table 6).

\subsection{DM characteristics}

Further exploring the future scenario of manufacturing, each of the DM characteristics is individually analysed. The characteristic classification, advantages and challenges are mapped to the various companies, supported by the most relevant statements from the experts' interviews. The parameters of the different characteristics are adapted either from literature or the frequency of occurrence in interviews. The advantages provide the main drivers for adopting the individual characteristics while the challenges highlight domains for future research. The supporting statements provide more insights about the way each characteristic affects the represented company/industry. The characteristics of 'Digitalisation', 'Personalisation', 'Localisation' and 'New Manufacturing Technologies' are analysed in the subsections that follow.

\subsubsection{Digitalisation}

On the one hand, companies offering products with moderate cost and volume are more aggressive in adopting digital tools in their operations (i.e. companies $D, E, G, H, I$ ). The primary 
expected advantage is improved 'Responsiveness' since information is delivered to the right recipient at the right time (Table 7). Digitalisation is also anticipated to improve 'Supply Chain Transparency' and 'Customer Interaction'.

On the contrary, companies relying on volume products (i.e. companies $C, D, E, F$ ) listed 'Supplier Trust/Competitiveness' as a potential challenge since a slight change in product/component cost could result in significant economic losses for the Original Equipment Manufacturers (OEMs). However, companies offering premium priced products (i.e. companies $E, G, H, J, K, L$ ) are more concerned about 'Intellectual Property' and 'Cyber Security' challenges. 
Table 7. Digitalisation - Analysis of cases.

\begin{tabular}{|c|c|c|c|c|c|c|c|c|c|c|c|c|c|c|}
\hline Digitalication & Darameter & & & & & & om & an & & & & & & \\
\hline Vigitalisation & Parameter & A & B & C & D & $\mathbf{E}$ & $\mathbf{F}$ & G & $\mathbf{H}$ & $\mathbf{I}$ & $\mathbf{J}$ & $\mathbf{K}$ & $\mathbf{L}$ & supporting statements \\
\hline \multirow{3}{*}{ Classification / Component } & Cloud Technologies & & & & $\checkmark$ & $\checkmark$ & & & & & & & & \multirow{3}{*}{$\begin{array}{l}\text { - "The supply chain will have to be such that } \\
\text { they've predicted what the order will be, it's } \\
\text { already in production and it's ready to go before } \\
\text { a customerorders it." [D] } \\
\text { "The more you can connect the manufacturing } \\
\text { process, the more you would be able to control } \\
\text { the automation and get the best quality at the } \\
\text { lowest cost." [G] }\end{array}$} \\
\hline & Internet of Things & & & & $\checkmark$ & $\checkmark$ & & $\checkmark$ & $\checkmark$ & $\checkmark$ & & & & \\
\hline & $\begin{array}{l}\text { ERP/Manufacturing } \\
\text { Execution System }\end{array}$ & $\checkmark$ & $\checkmark$ & $\checkmark$ & $\checkmark$ & $\checkmark$ & $\checkmark$ & $\checkmark$ & $\checkmark$ & $\checkmark$ & $\checkmark$ & $\checkmark$ & $\checkmark$ & \\
\hline \multirow{3}{*}{ Advantages } & $\begin{array}{l}\text { Supply Chain } \\
\text { Transparency }\end{array}$ & & & $\checkmark$ & $\checkmark$ & & & & $\checkmark$ & & $\checkmark$ & & & \multirow{3}{*}{ 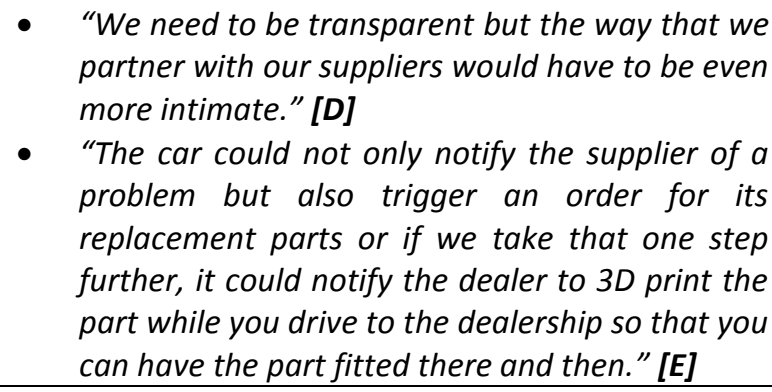 } \\
\hline & $\begin{array}{l}\text { Customer } \\
\text { Interaction }\end{array}$ & & & & & $\checkmark$ & $\checkmark$ & & & & & $\checkmark$ & & \\
\hline & Responsiveness & $\checkmark$ & $\checkmark$ & $\checkmark$ & $\checkmark$ & $\checkmark$ & $\checkmark$ & $\checkmark$ & & & $\checkmark$ & & $\checkmark$ & \\
\hline \multirow{3}{*}{ Challenges } & Cyber Security & & & & & $\checkmark$ & & $\checkmark$ & $\checkmark$ & & $\checkmark$ & $\checkmark$ & & \multirow{3}{*}{$\begin{array}{l}\text { - "Whatever designs we have for the implants, } \\
\text { companies wouldn't like to share the designs to } \\
\text { the cloud or to the suppliers." [F] } \\
\text { - "Cyber security is a big risk, you don't want } \\
\text { anyone to shut your manufacturing down and } \\
\text { hold you hostage." [G] } \\
\text { "There will be a lot of nervousness and potential } \\
\text { vulnerability regarding IP and when you } \\
\text { integrate the digital, virtual world, the design, } \\
\text { manufacturing and supply chain." [H] }\end{array}$} \\
\hline & $\begin{array}{l}\text { Intellectual } \\
\text { Property }\end{array}$ & & & & & & $\checkmark$ & $\checkmark$ & $\checkmark$ & & $\checkmark$ & $\checkmark$ & $\checkmark$ & \\
\hline & $\begin{array}{l}\text { Supplier Trust/ } \\
\text { Competitiveness }\end{array}$ & & & $\checkmark$ & $\checkmark$ & $\checkmark$ & $\checkmark$ & & & & & & & \\
\hline
\end{tabular}




\subsubsection{Personalisation}

All companies participated in this research are interested in providing more personalisation to customers, but still not perceive discontinuing standard/mass customisation production. Most of the company representatives believe that personalisation is an added-value feature/marketing strategy that would have to be marketed alongside the existing product portfolio. The personalisation-related advantages are claimed to be 'Customer Input Integration', 'Innovation - New Products' and 'Premium Product/Pricing' strategy (Table 8).

Companies depending on 'Economies-of-Scale' for profits consider this production strategy as a major limitation for providing personalisation. 'Product Complexity' is also a concerning factor for the medical equipment industry, considering the stringent rules and regulations in the industry. However, 'Ownership' of the product design, which is listed as a potential challenge for personalisation in literature, was not mentioned as an obstacle by any of the interviewed company representatives. 
Table 8. Personalisation - Analysis of cases.

\begin{tabular}{|c|c|c|c|c|c|c|c|c|c|c|c|c|c|c|}
\hline \multirow{2}{*}{ Personalisation } & \multirow{2}{*}{ Parameter } & \multicolumn{12}{|c|}{ Company } & \multirow{2}{*}{ Supporting Statements } \\
\hline & & A & B & C & D & $\mathbf{E}$ & $\mathbf{F}$ & $\mathbf{G}$ & $\mathbf{H}$ & I & $\mathbf{J}$ & $\mathrm{K}$ & $\mathbf{L}$ & \\
\hline \multirow{4}{*}{$\begin{array}{l}\text { Classification / } \\
\text { Component }\end{array}$} & Individualisation & $\checkmark$ & $\checkmark$ & $\checkmark$ & $\checkmark$ & $\checkmark$ & $\checkmark$ & $\checkmark$ & $\checkmark$ & & & $\checkmark$ & $\checkmark$ & \multirow{4}{*}{$\begin{array}{l}\text { - "In personal care, people are going to be wanting their own } \\
\text { colours and fragrances, and they're going to want to buy only as } \\
\text { much as they need." [D] } \\
\text { "The company tends to have a small number of choices in each } \\
\text { customisation that you make, but when you combine all the } \\
\text { customisations you can end up with very different cars." [E] } \\
\text { "We have had discussions with surgeons and that has happened, } \\
\text { but it doesn't happen all the time. I think it could be a trend in the } \\
\text { future." [G] } \\
\text { "We have 6,000 product variations that we currently produce." } \\
\text { [H] }\end{array}$} \\
\hline & $\begin{array}{l}\text { Product Family } \\
\text { Design }\end{array}$ & & & & & & & & $\checkmark$ & $\checkmark$ & $\checkmark$ & & & \\
\hline & $\begin{array}{c}\text { Mass } \\
\text { Customisation }\end{array}$ & $\checkmark$ & & & & $\checkmark$ & $\checkmark$ & $\checkmark$ & & & & & & \\
\hline & $\begin{array}{l}\text { Standard } \\
\text { Products }\end{array}$ & $\checkmark$ & $\checkmark$ & $\checkmark$ & $\checkmark$ & & $\checkmark$ & $\checkmark$ & & & $\checkmark$ & & & \\
\hline \multirow{3}{*}{ Advantages } & $\begin{array}{l}\text { Customer Input } \\
\text { Integration }\end{array}$ & & & & $\checkmark$ & $\checkmark$ & $\checkmark$ & & $\checkmark$ & $\checkmark$ & & & $\checkmark$ & \multirow{3}{*}{$\begin{array}{l}\text { - "We develop new flavours and variations in our products while } \\
\text { catering the needs of a specific event. With more customisation, } \\
\text { this could be a trend in the future." [B] } \\
\text { "The medical industry or the medical market which have more } \\
\text { complex products and are willing to pay higher prices for these } \\
\text { technologies." [G] } \\
\text { "I think customers want products how they want it in terms of } \\
\text { configurations, materials etc." [H] }\end{array}$} \\
\hline & $\begin{array}{c}\text { Innovation - New } \\
\text { Products }\end{array}$ & & $\checkmark$ & & & $\checkmark$ & & & & & $\checkmark$ & & & \\
\hline & $\begin{array}{c}\text { Premium } \\
\text { Product/Pricing }\end{array}$ & & & & & & & $\checkmark$ & & & & & & \\
\hline \multirow{3}{*}{ Challenges } & $\begin{array}{l}\text { Economies-of- } \\
\text { Scale }\end{array}$ & $\checkmark$ & $\checkmark$ & $\checkmark$ & $\checkmark$ & $\checkmark$ & & $\checkmark$ & & & & & & \multirow{3}{*}{$\begin{array}{l}\text { - "Biscuit is a commodity product, providing customisation will } \\
\text { never be economically viable considering the advantages of } \\
\text { economies-of-scale." [C] } \\
\text { "Medical products are very difficult to customise because there } \\
\text { are a lot of regulations. To do even a small change there is a long } \\
\text { process to get a lot of approvals." [F] } \\
\text { "Simple products that have very high volumes like syringes, I don't } \\
\text { think the technology is going to impact that kind of products in } \\
\text { the future." [G] }\end{array}$} \\
\hline & $\begin{array}{l}\text { Product } \\
\text { Complexity }\end{array}$ & $\checkmark$ & & & & & $\checkmark$ & $\checkmark$ & & & & & & \\
\hline & Ownership & & & & & & & & & & & & & \\
\hline
\end{tabular}




\subsubsection{Localisation}

Localisation, in the future, is regarded at a regional (i.e. about $50-500 \mathrm{~km}$ ) manufacturing and sourcing of components/products level (Table 9). However, most of the companies would decouple their manufacturing or outsource particular manufacturing operations to a different degree of localisation. This would enable the OEMs to implement economies-of-scale while benefiting from the advantages of localisation. 'Shorter Lead Time' is considered as the major driver of localisation by almost all the participant companies while increased 'Supply Chain Resilience' and 'Value Distribution' within the supply chain are expected to improve the KPIs of 'Responsiveness' and 'Agility'.

'High Cost: Labour \& Infrastructure' in multiple locations is the major challenge highlighted by companies providing low-cost products. On the other hand, high-end product manufacturers are concerned about 'Quality Control' issues and 'Resource Availability' in manufacturing operations, especially in distant sites, further raising concerns about the high maintenance costs of the manufacturing equipment. 
Table 9. Localisation - Analysis of cases.

\begin{tabular}{|c|c|c|c|c|c|c|c|c|c|c|c|c|c|c|}
\hline \multirow{2}{*}{ Localisation } & \multirow{2}{*}{ Parameter } & \multicolumn{12}{|c|}{ Company } & \multirow{2}{*}{ Supporting Statements } \\
\hline & & A & B & C & D & $\mathbf{E}$ & $\mathbf{F}$ & $\mathbf{G}$ & $\mathbf{H}$ & 1 & $\mathbf{J}$ & K & $\mathbf{L}$ & \\
\hline \multirow{4}{*}{ Classification / Component } & Local & $\checkmark$ & $\checkmark$ & & $\checkmark$ & & & $\checkmark$ & & & & & $\checkmark$ & \multirow{4}{*}{$\begin{array}{l}\text { - "Certain products, or certain raw materials which we } \\
\text { want to take advantage of in terms of scale, will be } \\
\text { made at a central location and then it'll be reachable to } \\
\text { say mini-factories or sort of automated factory vending } \\
\text { machines in super markets." [D] } \\
\text { "We have plants everywhere in the world as well and } \\
\text { we manufacture in every port we have our customers." } \\
\text { [G] } \\
\text { "The wind market is very much influenced by } \\
\text { government subsidies. Within the whole footprint of our } \\
\text { manufacturing we see the biggest bank for the buck in } \\
\text { terms of localisation." [J] }\end{array}$} \\
\hline & Regional & $\checkmark$ & $\checkmark$ & $\checkmark$ & $\checkmark$ & $\checkmark$ & $\checkmark$ & $\checkmark$ & & & $\checkmark$ & $\checkmark$ & & \\
\hline & Continental & & & & & $\checkmark$ & & & $\checkmark$ & $\checkmark$ & & & $\checkmark$ & \\
\hline & Global & & & & & & & & & & $\checkmark$ & & & \\
\hline \multirow{3}{*}{ Advantages } & $\begin{array}{c}\text { Shorter Lead } \\
\text { Time }\end{array}$ & $\checkmark$ & $\checkmark$ & $\checkmark$ & $\checkmark$ & $\checkmark$ & $\checkmark$ & & $\checkmark$ & $\checkmark$ & & $\checkmark$ & $\checkmark$ & \multirow{3}{*}{$\begin{array}{l}\text { - "I think there is always applications for distributed } \\
\text { manufacturing, and you don't want all your inventory } \\
\text { on a boat between countries and you don't want your } \\
\text { biggest warehouse to be on a ship in the ocean." [G] } \\
\text { - The extent of which we implement localisation could be } \\
\text { improved and that is our focus of how we can leverage } \\
\text { that to reduce our lead time for customers is key." [H] } \\
\text { "If we can reduce the lead time, definitely our market } \\
\text { share is going to improve." [K] }\end{array}$} \\
\hline & $\begin{array}{l}\text { Supply Chain } \\
\text { Resilience }\end{array}$ & & & $\checkmark$ & & & & & $\checkmark$ & $\checkmark$ & & & & \\
\hline & $\begin{array}{c}\text { Value } \\
\text { Distribution }\end{array}$ & & & & $\checkmark$ & $\checkmark$ & & $\checkmark$ & & & $\checkmark$ & & & \\
\hline \multirow{3}{*}{ Challenges } & Quality Control & & & & & & $\checkmark$ & & & $\checkmark$ & $\checkmark$ & & & \multirow{3}{*}{$\begin{array}{l}\text { - "You often don't get the perfect location at the perfect } \\
\text { price for the facility which could be another } \\
\text { disadvantage." [A] } \\
\text { "It will be interesting to see the difference between } \\
\text { shipping a car from plant in UK to China or shipping the } \\
\text { components because I don't think there will be much } \\
\text { difference in the two concepts." [E] } \\
\text { "Just weighing the costs between investment and } \\
\text { shipping is going to have a huge impact on the decision } \\
\text { to localise further." [H] }\end{array}$} \\
\hline & $\begin{array}{c}\text { High Cost: } \\
\text { Labour \& } \\
\text { Infrastructure }\end{array}$ & $\checkmark$ & $\checkmark$ & $\checkmark$ & $\checkmark$ & & & & $\checkmark$ & & & & $\checkmark$ & \\
\hline & $\begin{array}{l}\text { Resource } \\
\text { Availability }\end{array}$ & & & & & $\checkmark$ & & & & & $\checkmark$ & & & \\
\hline
\end{tabular}




\subsubsection{New manufacturing technologies}

Advanced manufacturing technologies mainly refer to automation via robotics and high-tech assembly lines. However, in the future, technologies like Cloud Manufacturing (Mai et al., 2016), Mini-factories (Rauch et al., 2016), Mobile Factories (Srai, Kumar et al., 2016), and Modular Factories (Matt et al., 2015) will emerge as enablers of DM. The aforesaid technologies were also the most frequently commented by the interviewees. Therefore, these manufacturing technologies are selected as components of the new manufacturing technologies DM characteristic.

More specifically, '3D Printing - Cloud Manufacturing' is considered as the most important enabler of DM for moderate and low volume products (Table 10). Instead, 'Mini-factories' are considered as the most important enabler for high volume products that could allow localised manufacturing to serve small, rather local, markets. 'Mobile Factories' require regulatory approval to be operational and are considered relevant for the case of manufacturing networks where logistics costs are considerable (Rauch et al., 2015a). In particular, the reconfigurability and scalability of 'Mobile Factories' has been validated to the case of the construction industry to improve material inventory and components' production lead time (Rauch et al., 2015b). On the contrary, 'Modular Factories' allow a certain degree of quantity flexibility. 'Customisation' and 'Manufacture on Demand' are listed as the major advantages of 3D printing that would allow OEMs to manufacture 'Complex Products'.

In terms of challenges, 'Quality Control' for mini-factories is a major concern whereas 'Maturity' of 3D printing is hindering OEMs from exploiting the technology at an industrial scale. There are also some limitations regarding the variety of 'Workable Materials' that can be used in existing 3D printing technologies. 
Table 10. New manufacturing technologies - Analysis of cases

\begin{tabular}{|c|c|c|c|c|c|c|c|c|c|c|c|c|c|c|}
\hline \multirow{2}{*}{$\begin{array}{c}\text { New Manufacturing } \\
\text { Technologies }\end{array}$} & \multirow{2}{*}{ Parameter } & \multicolumn{12}{|c|}{ Company } & \multirow{2}{*}{ Supporting Statements } \\
\hline & & A & B & C & D & $\mathbf{E}$ & $\mathbf{F}$ & G & $\mathbf{H}$ & I & J & $\mathbf{K}$ & $\mathbf{L}$ & \\
\hline \multirow{4}{*}{$\begin{array}{l}\text { Classification / } \\
\text { Component }\end{array}$} & $\begin{array}{l}\text { 3D Printing - } \\
\text { Cloud } \\
\text { Manufacturing }\end{array}$ & & & & $\checkmark$ & $\checkmark$ & $\checkmark$ & $\checkmark$ & $\checkmark$ & $\checkmark$ & & $\checkmark$ & $\checkmark$ & \multirow{4}{*}{$\begin{array}{l}\text { - "We could have smaller factories in the future, given that, } \\
\text { upcoming technologies provide us the liberty of quick } \\
\text { changeover and flexibility." [C] } \\
\text { "The car body shell is something in my mind that can be } \\
\text { internally standardised and save costs and then customise } \\
\text { the car in the dealership." [E] } \\
\text { "We are exploring what Industry } 4.0 \text { means to us in terms of } \\
\text { data analytics, digital manufacturing, the use of } \\
\text { collaborative robots, autonomous vehicles, flexible and } \\
\text { predictive manufacturing and how that could benefit us." [H] } \\
\text { "A factory that you can set up and pack it away and move it } \\
\text { to another place. That is something that we actually have } \\
\text { really urged our suppliers to come up with." [J] }\end{array}$} \\
\hline & Mini-factories & $\checkmark$ & $\checkmark$ & $\checkmark$ & $\checkmark$ & & & & & & & & & \\
\hline & Mobile Factories & & & & & & & & & & $\checkmark$ & & & \\
\hline & $\begin{array}{l}\text { Modular } \\
\text { Factories }\end{array}$ & & & & $\checkmark$ & $\checkmark$ & & & & $\checkmark$ & $\checkmark$ & & & \\
\hline \multirow{3}{*}{ Advantages } & $\begin{array}{l}\text { Manufacture on } \\
\text { Demand }\end{array}$ & & & & $\checkmark$ & & $\checkmark$ & & $\checkmark$ & & & & $\checkmark$ & \multirow{3}{*}{$\begin{array}{l}\text { - "We'll probably sell things in the future that are 3D printed, } \\
\text { something even in the consumer's home it could be, they're } \\
\text { - "Saking their own body wash." [D] } \\
\text { " manufacture using conventional technologies." [G] } \\
\text { - The supply chain would change because we won't need to } \\
\text { hold anymore parts in inventory since we will be able to print } \\
\text { on demand." [H] }\end{array}$} \\
\hline & $\begin{array}{l}\text { Complex } \\
\text { Products }\end{array}$ & & & & & & & $\checkmark$ & $\checkmark$ & $\checkmark$ & & $\checkmark$ & & \\
\hline & Customisation & & & & $\checkmark$ & $\checkmark$ & & $\checkmark$ & $\checkmark$ & $\checkmark$ & $\checkmark$ & $\checkmark$ & $\checkmark$ & \\
\hline \multirow{3}{*}{ Challenges } & Maturity & & $\checkmark$ & & $\checkmark$ & & $\checkmark$ & $\checkmark$ & $\checkmark$ & $\checkmark$ & $\checkmark$ & $\checkmark$ & $\checkmark$ & \multirow{3}{*}{$\begin{array}{l}\text { - Food items are very quality sensitive. New technologies } \\
\text { always require a long process of calibration and testing } \\
\text { before it is approved for production." [B] } \\
\text { - "If 3DP technology gets to a point where we can mass } \\
\text { produce complex components and things like that, it will } \\
\text { have a big influence how we manufacture engines and the } \\
\text { way in which we support our products." [H] } \\
\text { "For example, considering centring or coating, it's all batch } \\
\text { processes limited by the existing technology." [K] }\end{array}$} \\
\hline & $\begin{array}{l}\text { Workable } \\
\text { Materials }\end{array}$ & & & & & $\checkmark$ & & $\checkmark$ & & $\checkmark$ & $\checkmark$ & & & \\
\hline & Quality Control & $\checkmark$ & $\checkmark$ & $\checkmark$ & & $\checkmark$ & & & & & & & & \\
\hline
\end{tabular}




\section{Discussion and managerial implications}

This section explores implementation strategies for DM based on the 'product-process matrix'. Thereafter, a guideline for adopting centralised or decentralised manufacturing operations is discussed, based on the various products and processes of the examined companies. Lastly, the DCT is leveraged to correlate the DM characteristics and digitalisation enablers through integrating a research framework.

\subsection{DM application strategy}

The DM concept allows companies to achieve flexibility in manufacturing while providing personalised products in short lead times; however, it is challenging for companies to transit from traditional, batch manufacturing to smaller, more agile and distributed operations units. Considering the findings in this study, three manufacturing strategies have been devised to address this digital manufacturing transformation challenge, namely:

1. Small-scale distributed manufacturing

Small-scale distributed manufacturing denotes the manufacturing of moderate volume products in multiple locations while contemporarily providing mass customisation. This strategy involves the production large volumes of stock keeping units centrally and smallscale customised production near to consumption.

2. Decoupled manufacturing: In-house

In-house decoupled manufacturing aims at achieving economies-of-scale for primary manufacturing operations while attaining personalisation nearer to the consumer. This manufacturing strategy is capital intensive for the focal firm.

3. Decoupled manufacturing: Outsourced 
Outsourced decoupled manufacturing is characterised by the outsourcing of primary consumers.

The two decoupled manufacturing strategies (both in-house and outsourced) mainly deal with decoupling of manufacturing processes and moving the end-processes near to the consumption. This can be achieved in two ways: (i) in-house - a company performs the decoupled processes while maintaining ownership of manufacturing assets and processes; or (ii) outsourced - a company can outsource the decoupled processes and does not keep the ownership. All the involved companies were segregated into one of these three strategies based on discussions or similarity with their existing strategy (Figure 2). The mapping approaches of the current status along with the expected transition in future manufacturing scenarios were generated based on the direct input of the informants representing each company/industry.

Firstly, companies $A, B, C$ and $D$ are classified as small-scale distributed manufacturers as they focus on high volume and low-cost products. In this case, the manufacturing processes applied are continuous flow or connected line flow which would prevent, in the future, the decoupling of manufacturing operations. However, the manufacturing can be scaled down to achieve a flexible and agile manufacturing system. All other companies are able to decouple their manufacturing operations to harness the benefits of both centralised and decentralised systems. Secondly, companies $F, H, J$ and $K$ currently outsource some essential product components and would be willing to outsource the production of standard components by economies-of-scale; therefore, these companies are classified as decoupled manufacturing (outsourced). Thirdly, companies $E, G, I$ and $L$ are sceptical about sharing intellectual property and classified designs with suppliers; therefore, such firms are suitable for decoupled manufacturing (in-house). The following subsections further describe the three identified manufacturing strategies for applying DM while justifying the proposed solutions. 
Figure 2. DM application strategies.

\subsubsection{Small-scale distributed manufacturing}

This strategy proposes moderate volume manufacturing of products in multiple locations while providing mass customisation. The informant representing company $A$ commented that: "The distributed model has a lot of benefits, I think if we had to regrow it maybe we would go into having a lot more smaller facilities, I definitely see the merits of having localised manufacturing and sourcing of raw materials". Similar view regarding future strategies transcends other companies, as well. Therefore, commodity products in the FMCG industry (i.e. companies $A, B, C, D$ ) would be ideal for implementing the small-scale distributed manufacturing strategy in order to reduce the lead time and offer localised customisation. Mini-factories coupled with advanced ERP systems would be the 
enablers for this strategy. The transition for such companies is mapped in Figure 3 , by also adding a third dimension to the 'product-process matrix', namely the number of manufacturing facilities.

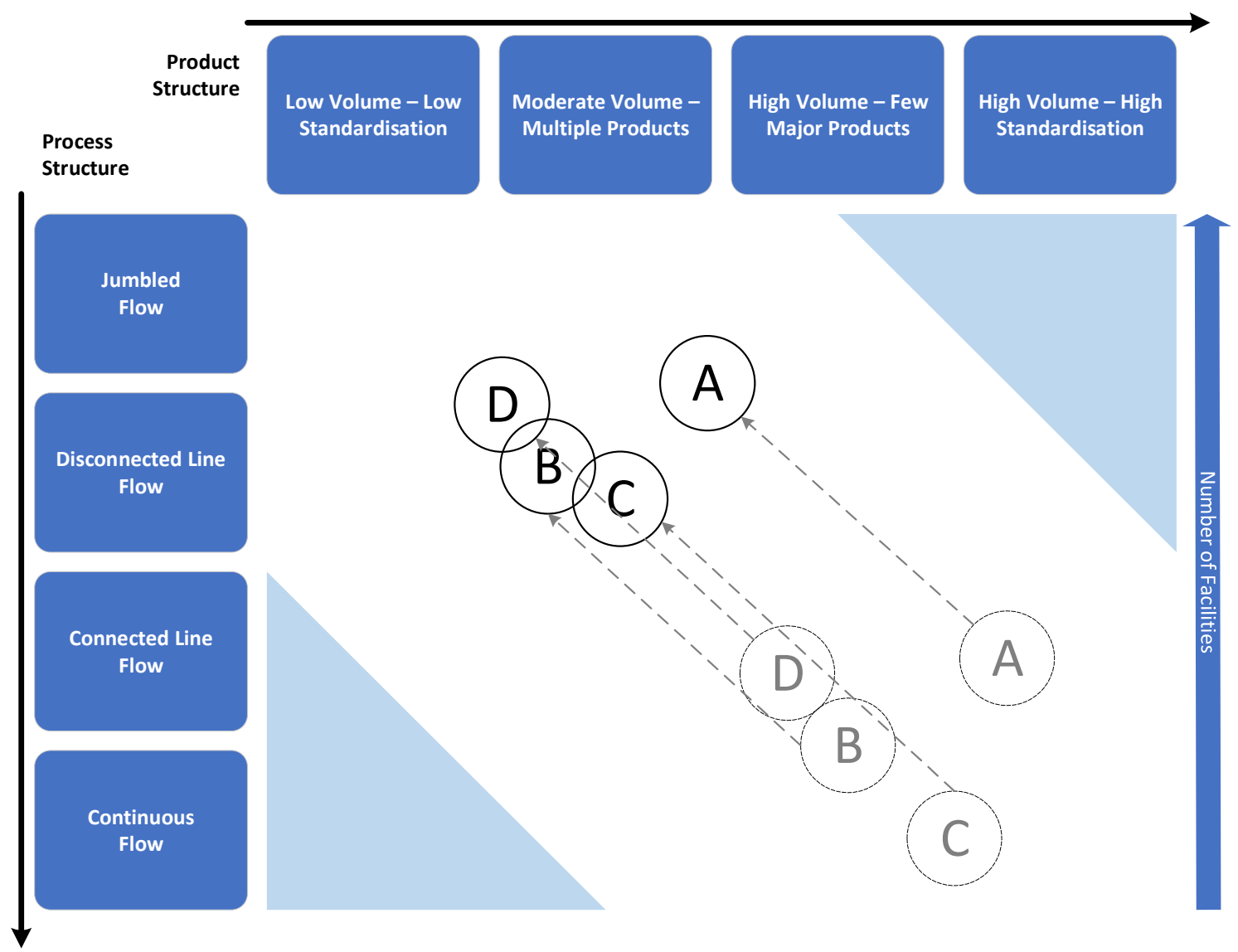

Figure 3. Small-scale distributed manufacturing.

\subsubsection{Decoupled manufacturing: In-house}

Decoupling the manufacturing operations would allow companies to achieve economies-of-scale for primary operations while attaining personalisation nearer to consumers, in the decoupled processes. The company's $L$ representative remarked that: "The entire base unit itself will have to be centrally manufactured because of the various processes and sourcing options available nearer to us and some of the more customer-specific parts could be manufactured closer to the installation site itself using 3D printing or other technologies". Other companies seem to share similar views 
regarding the decoupling of manufacturing operations closer to the consumers (i.e. companies $E, G$, $L, I)$.

The technological enablers of this strategy would be 3D printing via cloud computing, which is also the future strategy for most of the companies offering high-value products (i.e. companies $E, F$, $G, H, I, K, L)$. In company $J$, the preferred strategy is to employ 'Mobile Factories' or 'Modular Factories' to decouple manufacturing operations due to large and complex products (e.g. wind towers) which are not compatible with 3D printing technologies. However, with the maturity of 3D printing technology, most of the products would be able to adopt the strategy of decoupled manufacturing.

A transformation strategy for such companies is mapped in the 'product-process matrix' (Figure 4) with the number of manufacturing facilities added as the third dimension, as well. The transition state is generally split into two categories: (i) high volume - few major products; and (ii) low volume - low standardisation products. Therefore, the primary processes (denoted by dashed circles) for standard components could be centrally operated on a global or continental scale, with higher volumes to benefit from economies-of-scale. The products could then be personalised with design inputs from the customers by using 3D printers or other technologies at multiple locations with much lower production volume capabilities. The manufacturing capacity is thus balanced between the decoupled operations. High volume central facilities would be replaced by a network of low volume facilities located close to the consumers.

The process structure is jumbled flow for the processes operated through 3D printers since the products are manufactured individually. However, the primary processes can be quickly transformed into connected line flow to further enhance the economic viability of the proposed strategy. 
Figure 4. Decoupled manufacturing: In-house.

\subsubsection{Decoupled manufacturing: Outsourced}

The decoupled manufacturing strategy can be implemented by outsourcing the primary processes to suppliers and through providing personalised products to customers using advanced technologies located closer to the consumers. Indicatively, company's $H$ representative commented: "There will be an opportunity in the future where local development of suppliers will need product components quickly as well. The supplier base needs to be as flexible as us for the distributed model to work. With the technologies like 3D printing and digital enterprise, those issues will be addressed which will then enable the distributed manufacturing very easily". Few companies implement this strategy in the present scenario but can further enhance their operations by having multiple localised facilities closer to the consumer for their finishing processes (Figure 5). The size of a 
number of facilities allows companies with low volume manufacturing to decrease their operating capacities further.

In the decoupled manufacturing (outsourced) strategy the suppliers can provide standard components at a lower price using economies-of-scale, whereas, value-added processes can be operated closer to the consumers using 3D printing and cloud computing. Decoupled manufacturing would be suitable for companies willing to outsource manufacturing operations (i.e. companies $F, H$, $J, K)$, provided that the suppliers are willing to deliver the components to a distributed network of low volume manufacturing facilities.

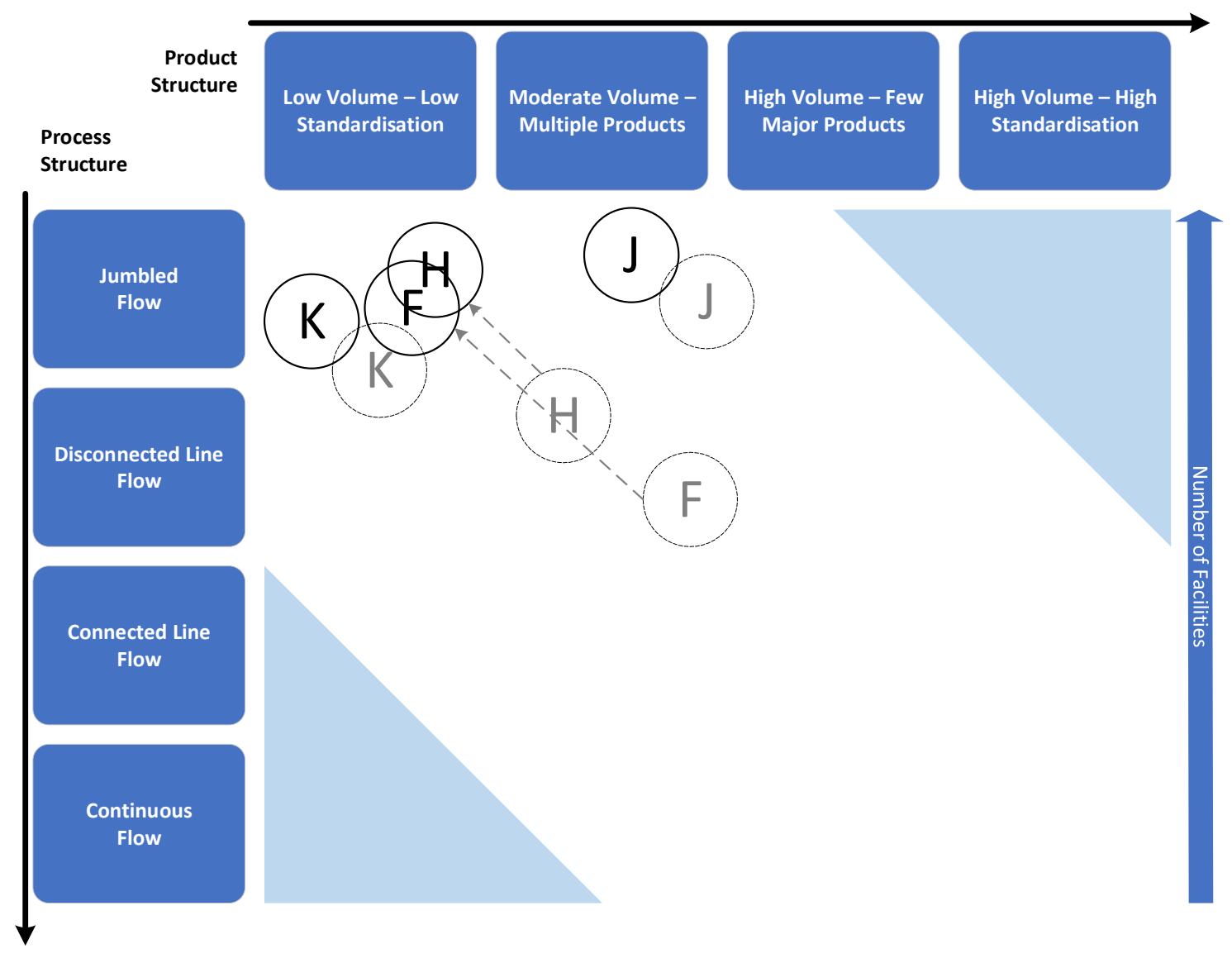

Figure 5. Decoupled manufacturing: Outsourced.

\subsection{Product-process classification}


In case the products are expensive and complex, require customisations and low volumes, then these should be manufactured in a distributed manufacturing system. On the other hand, high volume production of low cost, standard and simple components of a product should be manufactured centrally to benefit from economies-of-scale.

Nevertheless, the decision to decouple the manufacturing also depends on the manufacturing process. In case the process requires complex equipment and is heavily automated or is constrained by governmental regulations, then the manufacturing process should be performed centrally. On the 
contrary, processes which are semi-automated and do not require complex equipment can be flexibly operated in a geographically dispersed network of manufacturing facilities. Therefore, a complex and customised product, which can be manufactured through using simple equipment like for example a 3D printer, can be decoupled and localised close to the consumer. Table 11 is an initial analysis of suitable products and processes, but the parameters to decide the decoupling point for each industry will vary and a thorough review is required to achieve sustainable DM. Our findings regarding the manufacturing sectors demonstrating a potential towards a transition to DM are in accord with the findings of Rauch et al. (2018), with the most prominent example being the medical equipment manufacturers.

\subsection{Understanding DM strategies from the DCT perspective}

Different industries have various levels of personalisation, digitalisation and localisation. These characteristics, along with the tangible assets of a company, are defined as the existing resources in the proposed research framework which implies five stages of abstraction (Figure 6).

At Stage 1, a company should list the existing resources, based on the DCT, and understand the trends and variables transcending the manufacturing landscape (Birkinshaw et al., 2005). Digitalisation and new manufacturing technologies are confirmed, both in literature and through our research, to potentially impact the changing manufacturing industry environment in the future. However, dominant barriers towards this changing environment are existent. In this regard, at Stage 2, the resource-based DCT suggests that a firm-specific strategy is required to first identify any barriers, adapt and then integrate the existing firm resources to the changing environment in order to tackle these impediments. Following that, the concept of DM implies that a specific corporate strategy is adopted at Stage 3 to realise a competitive advantage by integrating the DM characteristics with a firm's existing operations. This adaptation to the changing environment would allow a company to develop DM capabilities (i.e. personalisation, localisation), at Stage 4. Finally, the adoption of KPIs at Stage 5 to evaluate a company's present and future performance is imminent to 
enable the effective digital enterprise transformation (Meier, 2016), and ensure the development of a sustainable competitive advantage.

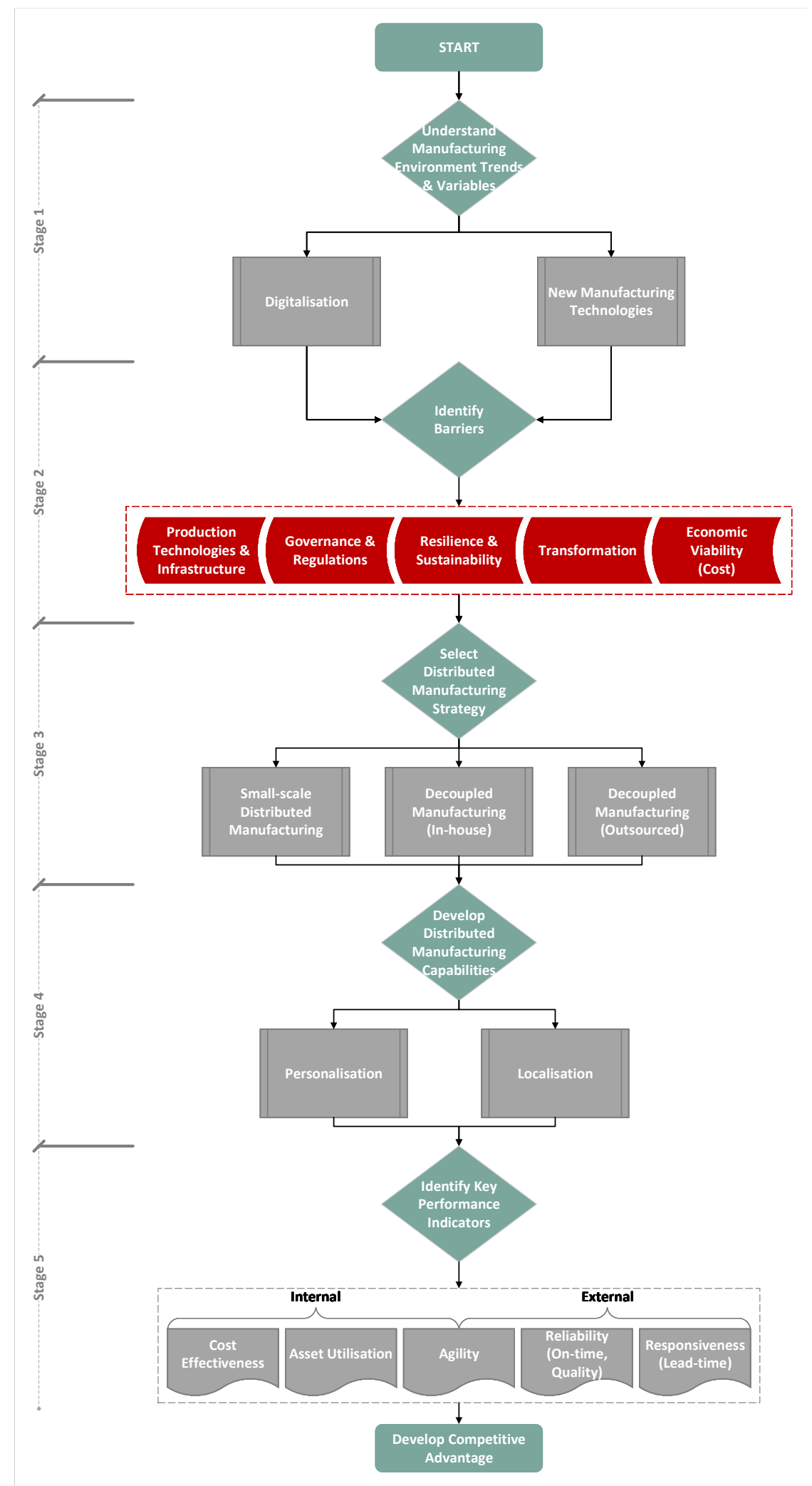

Figure 6. Framework for developing DM strategies following the DCT viewpoint. 
The DCT focusses on implementing manufacturing strategy without obstructing the existing presented in this study could be adopted by firms to inherit DM characteristics and thus improve their KPIs. For example, small-scale distributed manufacturing would provide localisation and regional mass-customisation, which could enhance external KPIs such as agility, reliability and responsiveness.

In this vein, decoupling the manufacturing operations would inherit all three characteristics of DM, hence improving both the internal and external KPIs to provide a sustainable competitive advantage to companies. Decoupled manufacturing (outsourced) would also exhibit multi-user participation by distributing the value chain amongst several participants (i.e. suppliers and distributors).

\section{Conclusions}

Digitalisation, personalisation and localisation integrated together to implement the concept of DM could provide companies with a competitive advantage in a highly dynamic manufacturing scenario. Technologies like 3D printing, loT and cloud computing are the key enablers to this concept and are continuously influencing the existing manufacturing operations in all industrial sectors.

DM application can be implemented via three strategies, namely: (i) Small-scale distributed manufacturing; (ii) Decoupled manufacturing: In-house; and (iii) Decoupled manufacturing: Outsourced. It is observed that DM for low cost, high volume and standardised products is not preferred by companies. Such products could be viable for regional localisation but cannot be manufactured locally. On the other hand, high value and customised products could be manufactured locally by using innovative technologies like 3D printing and other cloud technologies. There are various product properties that could help companies navigate the decision-making process for centralised or decentralised manufacturing. However, some of these products might be constrained by the manufacturing processes per se. It is observed that in case the production 
processes are heavily automated or require complex equipment, then companies prefer the traditional centralised manufacturing. Other factors that could also affect the decision upon adopting DM exist. Bespoke analysis of the product, process and location are required to implement any of these strategies based on the advantages and challenges of both centralised and distributed systems.

The major significant advantages of DM are found to be: (i) personalisation of products; (ii) reduced lead time for delivery of products; and (iii) supply chain transparency which would be enabled by emerging digital technologies like cloud computing, 3D printing and loT. Some indicative challenges identified are the maturity of new technologies, the dearth of economies-of-scale, and higher cost of infrastructure and resources in a geographically dispersed supply network. Further research to improve existing technologies would facilitate the reduction of operating costs in a DM model.

The DCT suggests that adaptation and integration of future technologies (changing environment) to the existing product portfolio could help companies achieve a competitive advantage. This advantage could be sustained via using the DM concept which correlates to the customer requirements. The consideration of the DCT helps to understand the phenomenon of DM and facilitates the execution of two manufacturing strategies. This contributes to the manufacturing strategy literature while laying the foundations for further research on digital and advanced manufacturing technologies. The characteristics of DM are also analysed based on the enablers, drivers and challenges pertaining to DM. The dynamic capabilities emerging from literature facilitate the evaluation of industrial KPIs to further verify the DM concept.

Industrial implications of this research include a comprehensive case of the DM concept exploring the various entailing advantages and challenges. Furthermore, this study provides companies with a preliminary guideline for the implementation of DM and strategic decisions that could be used in the process. Our findings also inform companies about the changing manufacturing environment in 
terms of new technologies and how these could be exploited to gain a competitive advantage through the characteristics of DM.

Considering the scope of this research, a few limitations are identified. Firstly, a small number of companies were interviewed which could have hindered the accuracy of the findings. Other industries and companies should be explored to obtain generalised results. Secondly, certain aspects of DM, like the location factor, could not be included in this study. A variety of companies dispersed geographically around the globe participating in future research projects on DM could provide more insights into this evolving paradigm. Additionally, the research conducted from a manufacturing firm's perspective and the interviewees are representatives of merely the focal company. The individual case studies hence limit the generalisation potential of the findings. Lastly, the mapping of the firms on the product-process matrix was based on the informants' input, thus attributing to the results a level of subjectivity. It would be interesting to verify the study findings by interviewing different stakeholders from each company/industry in the future. Other research methodologies, like surveys and framework validation techniques, could be implemented in future research to endorse the findings and conclusions of this study.

\section{Acknowledgement}

This research has received funding from the EPSRC under Reference No. EP/K02888X/1, Project Title: "Engineering Driven Sustainable Supply Networks - A UK/India Collaborative Study".

\section{References}

Ashby, A., 2016. From global to local: Reshoring for sustainability. Operations Management Research, 9(3-4), 75-88.

Bailey, D., De Propris, L., 2014. Manufacturing reshoring and its limits: The UK automotive case. Cambridge Journal of Regions, Economy and Society, 7(3), 379-395. 
Bechtsis, D., Tsolakis, N., Vlachos, D., lakovou, E., 2017. Sustainable supply chain management in the digitalisation era: The impact of Automated Guided Vehicles. Journal of Cleaner Production, 142(Part 4), 3970-3984.

Belkadi, F., Gupta, R.K., Vlachou, E., Bernard, A., Mourtis, D., 2016. Linking modular product structure to suppliers' selection through PLM approach: A frugal innovation perspective. In: Harik, R., Rivest, L., Bernard, A., Eynard, B., Bouras, A., (Eds.). PLM 2016: Product lifecycle management for digital transformation of industries. IFIP Advances in Information and Communication Technology, 492. Springer, Cham, 227-237.

Birkinshaw, J., Hood, N., Young, S., 2005. Subsidiary entrepreneurship, internal and external competitive forces, and subsidiary performance. International Business Review, 14(2), 227-248.

Blecker, T., Abdelkafi, N., Kaluza, B., Friedrich, G., 2006. Controlling variety-induced complexity in mass customisation: A key metrics-based approach. International Journal of Mass Customisation, $1(2 / 3), 272-298$.

Butala, P., Vrabič, R., Oosthuizen, G., 2013. Distributed manufacturing systems and the Internet of Things: A case study. In: Proceedings of the $25^{\text {th }}$ Annual South African Institute for Industrial Engineering Conference (SAlIE25). Stellenbosch: South Africa, July 9-11, 2013, Paper Ref. Nr. 565, 1-8.

Cao, G., Duan, Y., El Banna, A., 2018. A dynamic capability view of marketing analytics: Evidence from UK firms. Industrial Marketing Management, In Press.

Choi, T.Y., Dooley, K.J., Rungtusanatham, M., 2018. Supply networks and complex adaptive systems: Control versus emergence. Journal of Operations Management, 19(3), 351-366.

Chowdhury, M.M.H., Quaddus, M., 2017. Supply chain resilience: Conceptualization and scale development using dynamic capability theory. International Journal of Production Economics, $188,185-204$. 
Dalenogare, L.S., Benitez, G.B., Ayala, N.F., Frank, A.G., 2018. The expected contribution of Industry 4.0 technologies for industrial performance. International Journal of Production Economics, 204, 383-394.

Denzin, N.K., Lincoln, Y.S., 1994. Handbook of qualitative research. Thousand Oaks: Sage Publications.

Edmondson, A.C., McManus, S.E., 2007. Methodological fit in management field research. Academy of Management Review, 32(4), 1155-1179.

Enrriquez-De-La-O, J.F., 2015. Resource-based view and dynamic capabilities resource-based view and dynamic capabilities. Vezetéstudomány / Budapest Management Review, 46(11), 50-61.

Eriksson, T., Nummela, N., Saarenketo, S., 2014. Dynamic capability in a small global factory. International Business Review, 23(1), 169-180.

Frechtling, J., 2002. An Overview of Quantitative and Qualitative Data Collection Methods: The 2002 User-Friendly Handbook for Project Evaluation. Arlington: Directorate for Education and Human Resources, Division of Research, Evaluation and Communication, National Science Foundation, 43-62.

Furlan, A., Vinelli, A., 2018. Unpacking the coexistence between improvement and innovation in world-class manufacturing: A dynamic capability approach. Technological Forecasting and Social Change, 133, 168-178.

Gibbert, M., Ruigrok, W., Wicki, B., 2008, What passes as a rigorous case study?. Strategic Management Journal, 29(13), 1465-1474.

Gibson, I., Rosen, D., Stucker, B., 2010. Additive Manufacturing technologies: 3D printing, rapid prototyping, and direct digital manufacturing. New York: Springer. 
Gunasekaran, A., Subramanian, N., Ngai, W.T.E., 2019. Quality management in the 21st century enterprises: Research pathway towards Industry 4.0. International Journal of Production Economics, 207, 125-129.

Hayes, R.H., Wheelwright, S.C., 1979. Link manufacturing process and product life cycles. Harvard Business Review, 133-140.

Helo, P., Suorsa, M., Hao, Y., Anussornnitisarn, P., 2014. Toward a cloud-based manufacturing execution system for distributed manufacturing. Computers in Industry, 65(4), 646-656.

Huang, S.H., Liu, P., Mokasdar, A., Hou, L., 2013. Additive manufacturing and its societal impact: A literature review. International Journal of Advanced Manufacturing Technology, 67(5-8), 11911203.

Jaegler, A., Burlat, P., 2014. What is the impact of sustainable development on the re-localisation of manufacturing enterprises?. Production Planning and Control, 25(11), 902-911.

Jiang, W., Chai, H., Shao, J., Feng, T., 2018. Green entrepreneurial orientation for enhancing firm performance: A dynamic capability perspective. Journal of Cleaner Production, 198, 1311-1323.

Kamble, S.S., Gunasekaran, A., Sharma, R., 2018. Analysis of the driving and dependence power of barriers to adopt industry 4.0 in Indian manufacturing industry. Computers in Industry, 101, 107119.

Khaitan, S.K., McCalley, J.D., 2015. Design techniques and applications of cyberphysical systems: A survey. IEEE Systems Journal, 9(2), 350-365.

Kohtala, C., 2015. Addressing sustainability in research on distributed production: An integrated literature review. Journal of Cleaner Production, 106, 654-668.

Koren, Y., 2010. The global manufacturing revolution: Product-process-business integration and reconfigurable systems. New Jersey: John Willey \& Sons. 
Krause, D., Beckmann, G., Eilmus, S., Gebhardt, N., Jonas, H., Rettberg, R., 2014. Integrated development of modular product families: A methods toolkit. In: Simpson T., Jiao J., Siddique Z., Hölttä-Otto K., (Eds.). Advances in product family and product platform design. New York: Springer, 245-269.

Kumar, G., Subramanian, N., Arputham, R.M., 2018. Missing link between sustainability collaborative strategy and supply chain performance: Role of dynamic capability. International Journal of Production Economics, 203, 96-109.

Kumar, M., Graham, G., Hennelly, P., Srai, J.S., 2016. How will smart city production systems transform supply chain design: A product-level investigation. International Journal of Production Research, 54(23), 7181-7192.

Kumar, M., Gregory, M., 2013. An exploration of risk management in global industrial investment. Risk Management, 15(4), 272-300.

Lee, C.K.M., Lv, Y., Hong, Z., 2013. Risk modelling and assessment for distributed manufacturing system. International Journal of Production Research, 51(9), 2652-2666.

Love, P.E.D., Gunasekaran, A., 1997. Process reengineering: A review of enablers. International Journal of Production Economics, 50(2-3), 183-197.

Mai, J., Zhang, L., Tao, F., Ren, L., 2016. Customized production based on distributed 3D printing services in cloud manufacturing. The International Journal of Advanced Manufacturing Technology, 84(1-4), 71-83.

Markets and Markets, 2017. Industry 4.0 Market by Technology (Industrial Robotics, Cyber Security, Internet of Things, 3D Printing, Advanced Human-Machine Interface, Big Data, Augmented Reality \& Virtual Reality, Artificial Intelligence), Vertical, Region - Global Forecast to 2022. [online] Available at: https://www.marketsandmarkets.com/PressReleases/industry-4.asp (accessed 17 November 2018). 
Matt, D.T., Orzes, G., Rauch, E., Dallasega, P., 2018. Urban production - A socially sustainable factory concept to overcome shortcomings of qualified workers in smart SMEs. Computers and Industrial Engineering, In Press.

Matt, D.T., Rauch, E., Dallasega, P., 2015. Trends towards Distributed Manufacturing Systems and modern forms for their design. Procedia CIRP, 33, 185-190.

Meier, C., 2016. Digital supply chain management. In: Uhl A., Gollenia L.A., (Eds.). Digital enterprise transformation: A business-driven approach to leveraging innovative IT. New York: Routledge, 231-262.

Mintzberg, H., Ahlstrand, B., Lampel, J., 2008. Strategy Safari: The complete guide through the wilds of strategic management. Toronto: Pearson Education Canada.

Mishra, N., Singh, A., Kumari, S., Govindan, K., Ali, S.I., 2016. Cloud-based multi-agent architecture for effective planning and scheduling of distributed manufacturing. International Journal of Production Research, 54(23), 7115-7128.

Moreno M., Charnley F., 2016. Can re-distributed manufacturing and digital intelligence enable a regenerative economy? An integrative literature review. In: Setchi R., Howlett R., Liu Y., Theobald P., (Eds.). Sustainable design and manufacturing 2016. Smart Innovation, Systems and Technologies, 52. Cham: Springer, 563-575.

Moreno, M., Court, R., Wright, M., Charnley, F., 2018. Opportunities for redistributed manufacturing and digital intelligence as enablers of a circular economy. International Journal of Sustainable Engineering, In Press.

Mourtzis, D., Doukas, M., 2012. Decentralized manufacturing systems review: Challenges and outlook. Logistics Research, 5(3-4), 113-121. 
Mourtzis, D., Doukas, M., 2013. Decentralized manufacturing systems review: Challenges and outlook. In: Windt K., (Eds.). Robust manufacturing control. Lecture Notes in Production Engineering. Berlin: Springer, 355-369.

Mourtzis, D., Doukas, M., 2014. Design and planning of manufacturing networks for mass customisation and personalisation: Challenges and outlook. Procedia CIRP, 19, 1-13.

Mourtzis, D., Vlachou, E., Boli, N., Gravias, L., Giannoulis, C., 2016b. Manufacturing networks design through smart decision making towards frugal innovation. Procedia CIRP, 50, 354-359.

Mourtzis, D., Vlachou, E., Giannoulis, C., Siganakis, E., Zogopoulos, V., 2016a. Applications for frugal product customization and design of manufacturing networks. Procedia CIRP, 52, 228-233.

Muhuri, P.K., Shukla, A.K., Abraham, A., 2019. Industry 4.0: A bibliometric analysis and detailed overview. Engineering Applications of Artificial Intelligence, 78, 218-235.

Noor, K.B.M., 2008. Case study: A strategic research methodology. American Journal of Applied Sciences, 5(11), 1602-1604.

O’Donovan, P., Leahy, K., Bruton, K., O'Sullivan, D.T.J., 2015. An industrial big data pipeline for datadriven analytics maintenance applications in large-scale smart manufacturing facilities. Journal of Big Data, 2, 25.

Pearson, H., Noble, G., Hawkins, J., 2013. Re-distributed manufacturing. Swindon: Engineering and Physical Sciences Research Council.

Peng, D.X., Schroeder, R.G., Shah, R., 2008. Linking routines to operations capabilities: A new perspective. Journal of Operations Management, 26(6), 730-748.

Quezada, L.E., Chiu, A.S.F., Gouvea da Costa, S.E., Tan, K.H., 2017. Operational Excellence towards Sustainable Development Goals through Industry 4.0. International Journal of Production Economics, 190, 1-2. 
Rauch, E., Dallasega, P., 2017. Sustainability in manufacturing and supply chains through distributed manufacturing systems and networks. In: Abraham, M.A., (Eds.). Encyclopedia of sustainable technologies. Oxford: Elsevier, 429-438.

Rauch, E., Dallasega, P., Matt, D.T., 2016. Sustainable production in emerging markets through Distributed Manufacturing Systems (DMS). Journal of Cleaner Production, 135, 127-138.

Rauch, E., Matt, D.T., Dallasega, P., 2015a. Mobile Factory Network (MFN) - Network of flexible and agile manufacturing systems in the construction industry. Applied Mechanics and Materials, 752$753,1368-1373$.

Rauch, E., Matt, D.T., Dallasega, P., 2015b. Mobile On-site Factories - Scalable and distributed manufacturing systems for the construction industry. In: Proceedings of the 2015 International Conference on Industrial Engineering and Operations Management. Dubai: United Arab Emirates, March 3-5.

Rauch, E., Unterhofer, M., Dallasega, P., 2018. Industry sector analysis for the application of additive manufacturing in smart and distributed manufacturing systems. Manufacturing Letters, 15(Part B), 126-131.

Rejeski, D., Zhao, F., Huang, Y., 2018. Research needs and recommendations on environmental implications of additive manufacturing. Additive Manufacturing, 19, 21-28.

Rymaszewska, A., Helo, P., Gunasekaran, A., 2017. loT powered servitization of manufacturing - An exploratory case study. International Journal of Production Economics, 192, 92-105.

Safizadeh, M.H., Ritzman, L.P., Sharma, D., Wood, C., 1996. An empirical analysis of the productprocess matrix. Management Science, 42(11), 1576-1591.

Saunders, M.N.K., Lewis, P., Thornhill, A., 2015. Research Methods for Business Students. Essex: Pearson Education Limited.

Schumpeter, J.A., 1934. Theory of economic development. Cambridge: Harvard University Press. 
Schwandt, T.A., 1994. Qualitative data analysis: An expanded sourcebook. In: Miles, M.B., Huberman, A.M., (Eds.). Thousand Oaks: Sage. Evaluation and program planning, 19(1), 106-107.

Spallek, J., Krause, D., 2016. Process types of customisation and personalisation in design for additive manufacturing applied to vascular models. Procedia CIRP, 50, 281-286.

Spencer, M.S., Cox, J.F., 1995. An analysis of the product-process matrix and repetitive manufacturing. International Journal of Production Research, 33(5), 1275-1294.

Srai, J.S., Harrington, T.S., Tiwari, M.K., 2016. Characteristics of redistributed manufacturing systems: A comparative study of emerging industry supply networks. International Journal of Production Research, 54(23), 6936-6955.

Srai, J.S., Kumar, M., Graham, G., Phillips, W., Tooze, J., Ford, S., Beecher, P., Raj, B., Gregory, M., Tiwari, M.K., Ravi, B., Neely, A., Shankar, R., Charnley, F., Tiwari, A., 2016. Distributed manufacturing: Scope, challenges and opportunities. International Journal of Production Research, 54(23), 6917-6935.

Sung, T.K., 2018. Industry 4.0: A Korea perspective. Technological Forecasting and Social Change, $132,40-45$

Teece, D.J., Pisano, G., Shuen, A., 1997. Dynamic capabilities and strategic management. Strategic Management Journal, 18(7), 509-533.

Tranfield, D., Denyer, D., Smart, P., 2003. Towards a methodology for developing evidence-informed management knowledge by means of systematic review. British Journal of Management, 14(3), 207-222.

Tseng, M.M., Jiao, R.J., Wang, C., 2010. Design for mass personalization. CIRP Annals - Manufacturing Technology, 59(1), 175-178.

Turner, C., Tiwari, A., Pizarroso, J.L.R., Moreno, M., Vladimirova, D., Zaki, M., Geißdörfer, M., 2017. Digital redistributed manufacturing (RdM) studio: A data-driven approach to business model 
development. In: Campana, G., Howlett, R., Setchi, R., Cimatti, B., (Eds.). Sustainable design and manufacturing: Smart innovation, systems and technologies. Cham: Springer, 515-524.

Wang, S., Wan, J., Zhang, D., Li, D., Zhang, C., 2016. Towards smart factory for industry 4.0: A selforganized multi-agent system with big data based feedback and coordination. Computer Networks, 101, 158-168.

Waytz, A., Norton, M.I., 2014. Botsourcing and outsourcing: Robot, British, Chinese, and German workers are for thinking-not feeling-jobs. Emotion, 14(2), 434-444.

Weller, C., Kleer, R., Piller, F.T., 2015. Economic implications of 3D printing: Market structure models in light of additive manufacturing revisited. International Journal of Production Economics, 164, 43-56.

Wilson, H., Daniel, E., 2007. The multi-channel challenge: A dynamic capability approach. Industrial Marketing Management, 36(1), 10-20.

Wittbrodt, B.T., Glover, A.G., Laureto, J., Anzalone, G.C., Oppliger, D., Irwin, J.L., Pearce, J.M., 2013. Life-cycle economic analysis of distributed manufacturing with open-source 3-D printers. Mechatronics, 23(6), 713-726.

Yao, J., Deng, Z., 2016. Dynamic resource integration optimisation of global distributed manufacturing: An embeddedness-interaction perspective. International Journal of Production Research, 54(23), 7143-7157.

Yin, R.K., 2009. Case study research: Design and methods. Thousand Oaks: Sage Publications. 


\section{Appendix}

Table A1. Exploratory case introductions - Industry, product and customers.

\begin{tabular}{|c|c|c|c|}
\hline Company & Industry & Product & Customers \\
\hline A & FMCG & $\begin{array}{l}\text { Ingredients based on Meal Box } \\
\text { Recipes for customers to cook at } \\
\text { home }\end{array}$ & $\begin{array}{l}\text { Young professionals and families } \\
\text { who do not have time to get } \\
\text { ingredients but want to try } \\
\text { something new to eat }\end{array}$ \\
\hline B & FMCG & Food products - snacks and sweets & $\begin{array}{l}\text { Usually Indian people in India and } \\
\text { globally }\end{array}$ \\
\hline C & FMCG & Whole wheat biscuits & Indian market \\
\hline D & FMCG & $\begin{array}{l}\text { Consumer products - personal care } \\
\text { and food }\end{array}$ & Global \\
\hline $\mathrm{E}$ & Automotive & Medium and high-end cars & Car owners - global \\
\hline $\mathrm{F}$ & $\begin{array}{l}\text { Medical } \\
\text { Equipment }\end{array}$ & $\begin{array}{l}\text { Medical devices and equipment } \\
\text { used in orthopaedic, urology and } \\
\text { radiology }\end{array}$ & $\begin{array}{l}\text { Hospitals and clinics in India and } \\
\text { exporting to other developing } \\
\text { countries }\end{array}$ \\
\hline G & $\begin{array}{l}\text { Medical } \\
\text { Equipment }\end{array}$ & $\begin{array}{l}\text { Disposable medical devices, } \\
\text { reagents and high-end diagnostic } \\
\text { equipment }\end{array}$ & $\begin{array}{l}\text { Hospitals, clinics and patients - } \\
\text { global }\end{array}$ \\
\hline $\mathrm{H}$ & Engines & Medium and large engines & $\begin{array}{l}\text { OEMs and distributors for } \\
\text { construction equipment, power } \\
\text { generation, industrial applications } \\
\text { etc. }\end{array}$ \\
\hline 1 & Engines & Aerospace engines & Civil and defence aerospace - global \\
\hline$J$ & $\begin{array}{l}\text { Renewable } \\
\text { Energy }\end{array}$ & $\begin{array}{l}\text { Off-shore and on-shore wind } \\
\text { turbines }\end{array}$ & $\begin{array}{l}\text { Wind Farm developers, investors, } \\
\text { utility companies and energy } \\
\text { providers-global }\end{array}$ \\
\hline K & $\begin{array}{l}\text { Industrial } \\
\text { Machines }\end{array}$ & $\begin{array}{l}\text { Bespoke solutions for cutting tools } \\
\text { and cutting tool holders }\end{array}$ & $\begin{array}{l}\text { Indian industries processing metal } \\
\text { like automotive, defence and } \\
\text { aerospace establishments }\end{array}$ \\
\hline $\mathrm{L}$ & $\begin{array}{l}\text { Industrial } \\
\text { Machines }\end{array}$ & Industrial machinery & Biscuit factories - global \\
\hline
\end{tabular}

